\title{
日本で望まれる機械安全に関する法規制及び社会制度の考察 †
}

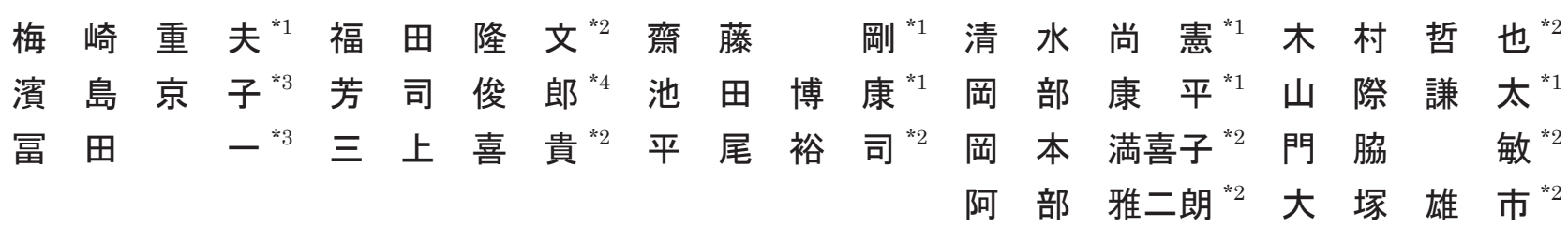

日本の強みは，現場の優秀な作業者や管理・監督者及び生産技術者が質の高い安全管理と生産技術に基づく 改善を実施していることにある。したがって，この“現場力”を基盤に置いた上で，技術に基づく安全の先進国 と言われる欧州の機械安全技術や社会制度を適切に活用寸れば，日本の現場力と欧州の機械安全技術を高次の次 元で融合させた新しい枠組みの安全技術と社会制度を構築できる可能性がある。本稿では，以上の観点から日本 で望まれる法規制及び社会制度のあり方を検討した。その結果，今後の日本の社会制度では，安全をコストでな く新たな価值創造のための投資として位置づけること，高い当事者意識と安全な職場を構築しようとする共通の 価值観を関係者間で共有すること，及び再発防止から未然防止，件数重視から重篤度重視への戦略転換と想定外 の考慮が重要と推察された。また，実際の機械の労働災害防止対策では，特に経営者及び設計者に対して欧州機 械安全の基本理念と災害防止原則を普及促進するとともに，(1) ISO12100 に定めるリスク低減戦略，(2)モジュー ル方式による適合性評価と適合宣言に関する情報伝達を目的としたマーキング，(3マーキングの情報に基づく機 械の使用段階での妥当性確認，(4)機械の設計・製造段階への災害情報のフィードバックが特に重要と考えられた.

キーワード：機械安全，法規制，社会制度，ISO 12100 , 妥当性確認

\section{1 はじめに}

欧州の機械安全に関する法規制及び社会制度の基本的 枠組みは，1985 年のニュー・アプローチ政策によって確 立したと考えられる。この政策では，(1)安全上の必須要 求事項である欧州指令とこれを補完する体系的な技術仕 様書である $\mathrm{EN}$ 規格, (2)モジュール方式による適合性評 価と欧州域内での相互承認，(3)自己責任に基づき製品の 必須要求事項への適合を自ら宣言する CE マーキングな どが，日本の労働災害防止対策でも大変参考になると考 えられる ${ }^{1 \sim 3)}$. このため, 本稿では, 上記(1)〜(3)の法規 制や社会制度を日本の労働安全分野でも活用することに よって，機械に起因する労働災害の大幅な減少が図れる かの検証を進めている.

このような検証を実施する場合，日本と欧州の社会的・ 文化的背景を考慮して比較検討を行う必要がある。例え ば，欧州で設備対策を中心とした保護方策が普及した背 景には，人や物の自由な移動が不可欠な欧州域内で母国 語や文化も異なる多様な労働者を雇用する場合, ガード や保護装置などの設備対策の充実が最も効果的な安全確 保の方法であったためと考えられる.

これに対し，日本では，現場の優秀な作業者や管理・

†原稿受付 2014年08月 22 日

$\dagger$ 原稿受理 2014年10月06日

J-STAGE Advance published date: November 14, 2014

*1 (独)労働安全衛生総合研究所機械システム安全研究グルーフ

$* 2$ 国立大学法人長岡技術科学大学大学院 技術経営研究科

*3 (独)労働安全衛生総合研究所 電気安全研究グループ

*4 厚生労働省労働基準局安全衛生部安全課

前 (独)労働安全衛生総合研究所 機械システム安全研究グループ

連絡先：干204-0024 東京都清瀬市梅園1-4-6

(独)労働安全衛生総合研究所機械システム安全研究グループ 梅崎重夫"

E-mail: umezaki@s.jniosh.go.jp
監督者及び生産技術者の技能と注意力に依存して質の高 い安全管理と生産技術に基づく改善を実施している場合 も多いと考えられる。これは，最近の雇用の流動化や就 業形態の多様化などに起因して後退が著しいが，鉄鋼， 自動車，化学，電機などの分野では依然として健在な企 業も認められる。

したがって，日本の強みである “現場力”に基づく質 の高い安全管理と生産技術を基盤に置いた上で，安全の 先進国と言われる欧州の機械安全技術や社会制度を適切 に活用すれば，多発している機械による労働災害の激減 を図ることも可能と考えられる。また，この成果を基に， 日本の現場力と欧州の機械安全技術を高次の次元で融合 させた新しい枠組みの安全技術を海外に向けて広く発信 できる可能性がある。これは, 働く人の安全 (労働者保護) だけでなく, 日本の国際競争力の強化という観点からも 意義がある。

本稿では“現場力”を“経営者が定めた経営戦略を達 成するために，作業者や管理・監督者及び生産技術者な ごが現場の実情に応じた適切な解決策を組織的に提案し 実行する能力” と定義した。ここでいう解決策の中では, 安全・品質 - 環境の確保, 生産性の改善, 原価の低減, 納期の遵守などが特に重要と考えられる。この詳細は第 3 章の 2) を参照されたい.

本稿は，以上の観点から，今後の日本で望まれる法規 制及び社会制度のあり方について文献 1）～4）の記載も 考慮した上で考察を行う。なお，“現場力”に基づく安全 管理では，事業者と労働者の間で“自分たちの職場から は重大な労働災害を発生させない”とする価值観の共有 が不可欠である。 
また，“現場力”を過信して設備対策が可能なものに まで無理に人の注意力に依存する対策を実施する場合は, そのような対策自体が労働災害の直接原因となることも ある。したがって，“現場力”の活用にあたっては，人の 誤りや機械の故障が発生した場合でも事故や災害に至ら ないための設備対策をあらかじめ講じておくことが，安 全な職場を実現する際に不可欠な条件となる. 同様に, 安全に関する企業の競争力強化に関しても, 働く人の安 全を優先した対応が不可欠である.

\section{2 欧州の機械安全に関する法規制及び社会制度の概要}

最初に本稿の前提条件を明確にするために，欧州の機 械安全に関する法規制と社会制度の核心である (1) EU 指
令と EN 規格，(2)機械のリスク低減戦略の概要，(3)モ ジュール方式による適合性評価，(4適合宣言と CE マー キングの概要を文献 2) 及び 3) での記載を基に述べる ${ }^{2,3}$.

これらの情報は機械安全の専門家にとっては既知であ るが，前提条件の明確化と多くの方々に関連情報を知っ てもらうために記載した。 なお，本稿で使用する略語及 び用語の意味は表 1 及び表 2 を参照されたい.

\section{1） EU 指令の発令と EN 規格の制定}

1957 年に設立された EEC は，EEC 内での製品の自由 な流通が安全規制という障壁によって阻害されるのを防 ぐために，CEN/CENEREC（欧州の規格制定機関）が 中心となって加盟国相互の規格の整合化を推進してきた. この政策は“オールド・アプローチ”と呼ばれる.

表1＼cjkstart本稿で使用する略語の意味

\begin{tabular}{|c|c|c|c|}
\hline \multicolumn{2}{|r|}{ 略語 } & 日本語での名称 & $\begin{array}{lll}\text { 説 } & \text { 明 } \\
\end{array}$ \\
\hline 1 & EU & 欧州連合 & 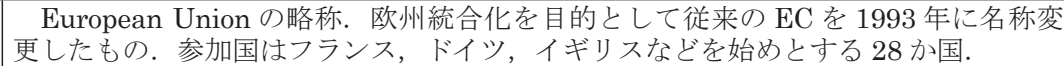 \\
\hline 2 & EC & 欧州共同体 & $\begin{array}{l}\text { European Communities の略称. } \\
\text { 欧州での単一共同市場の構築を目的として } 1967 \text { 年に設立された. }\end{array}$ \\
\hline 3 & EEC & 欧州経済共同体 & $\begin{array}{l}\text { European Economic Community の略称. } \\
\text { E Cの母体となった経済共同体であり，1957 年に設立された。 }\end{array}$ \\
\hline 4 & $\mathrm{CE}$ & CE マーキング & $\begin{array}{l}\text { Comite Europeen の略称. 製品が EC 指令の必須要求事項に適合していることを, } \\
\text { 製造者自らが適合宣言するとき貼付するマーキング. }\end{array}$ \\
\hline 5 & ISO & 国際標準化機構 & $\begin{array}{l}\text { International Standardization Organization の略称. } 1947 \text { 年に電気・電子分野以 } \\
\text { 外の標準化のための国際機関として設立された. }\end{array}$ \\
\hline 6 & IEC & 国際電気標準化機構 & $\begin{array}{l}\text { International Electrotechnical Commission の略称. } 1908 \text { 年に電気・電子分野の } \\
\text { 標準化のための国際機関として設立された. }\end{array}$ \\
\hline 7 & CEN & 欧州標準化委員会 & $\begin{array}{l}\text { Comite Europeen de Normalisation の略称. 欧州域内の電気・電子分野以外の標 } \\
\text { 準化のための機関として設立された機構. }\end{array}$ \\
\hline 8 & CENELEC & 欧州電気標準化委員会 & $\begin{array}{l}\text { Comite Europeen de Normalisation Electro-technique の略称. 欧州域内の電気・ } \\
\text { 電子分野の標準化のための国際機関として設立された機構. }\end{array}$ \\
\hline 9 & EN & 欧州規格 & European Norms の略称．最終的に確定した欧州規格である. \\
\hline
\end{tabular}

表2ＩSO12100（JISB9700）で使用する用語の意味

\begin{tabular}{|c|c|c|c|}
\hline \multicolumn{2}{|r|}{ 用 語 } & \multirow[t]{2}{*}{ 英語表記 } & 定 義 \\
\hline 1 & $\begin{array}{l}\text { 機械類 } \\
\text { 機械 }\end{array}$ & & $\begin{array}{l}\text { 連結された部品又は構成品の組合せで, そのうちの少なくとも二つは適切な機 } \\
\text { 械アクチュエータ, 制御及び動力回路を備えて動くものであって, 特に材料の } \\
\text { 加工, 処理, 移動, 相包といった特の用途に合うように結合されたもの }\end{array}$ \\
\hline 2 & 危害 & Harm & 身体的傷害又は健康障害 \\
\hline 3 & 危険源 & Hazard & 危害を引き起こす潜在的根源 \\
\hline 4 & 危険状態 & Hazardous situation & 人が少なくとも一つの危険源に暴露される状況 \\
\hline 5 & 危険事象 & Harmful event & 危険状態から結果として危害に至る出来事 \\
\hline 6 & 危険区域 & $\begin{array}{l}\text { Hazard zone } \\
\text { Danger zone }\end{array}$ & 人が危険源に暴露されるような機械類の内部及び/ 又は機械類周辺の空間 \\
\hline 7 & リスク & Risk & 危害の発生確率と危害のひどさの組合せをいう. \\
\hline 8 & リスクアセスメント & Risk assessment & リスク分析及びリスクの評価を含む寸べてのプロセス \\
\hline 9 & 適切なリスク低減 & $\begin{array}{l}\text { Adequate risk } \\
\text { reduction }\end{array}$ & $\begin{array}{l}\text { 現在の技術レベルを考慮した上で, 少なくとも法的要求事項にしたがったリス } \\
\text { クの低減 }\end{array}$ \\
\hline 10 & 保護方策 & Protective measure & $\begin{array}{l}\text { リスク低減を達成することを意図した方策. 設計者による本質的安全設計方策, } \\
\text { 安全防護及び付加保護方策, 使用上の情報の提供, 及び使用者による安全管理 } \\
\text { 組織の整備, 安全作業手順の策定, 監督, 作業許可システムの構築, 追加安全 } \\
\text { 訪護物の準備及び使用, 保護具の使用, 訓練などが該当する. }\end{array}$ \\
\hline 11 & 本質的安全設計方策 & $\begin{array}{l}\text { Inherently safe design } \\
\text { measure }\end{array}$ & $\begin{array}{l}\text { ガード又は保護装置を使用しないで, 機械の設計又は運転特性を変更すること } \\
\text { により危険源を除去するか又は危険源に関連するリスク低減する保護方策 }\end{array}$ \\
\hline 12 & 安全防護 & Safeguarding & $\begin{array}{l}\text { 本質的安全設計方策によっては合理的に除去できない危険源, 又は十分に低減 } \\
\text { できないリスクか保護方策 }\end{array}$ \\
\hline 13 & 使用上の情報 & Information for use & $\begin{array}{l}\text { 使用者に情報を伝えるための伝達手段（例えば, 文章, 語句, 標識, 信号, 記号, } \\
\text { 図形) を個別に, 又は組み合わせて使用する保護方策 }\end{array}$ \\
\hline 14 & 機械の意図する使用 & $\begin{array}{l}\text { Intended use of a } \\
\text { machine }\end{array}$ & 使用上の指示事項の中に提供された情報に基づく機械の使用 \\
\hline 15 & $\begin{array}{l}\text { 合理的に予見可能な } \\
\text { 誤使用 }\end{array}$ & $\begin{array}{l}\text { Reasonably foreseeable } \\
\text { misuse }\end{array}$ & $\begin{array}{l}\text { 設計者が意図していない使用法で, 容易に予測し得る人間の挙動から生じる機 } \\
\text { 械の使用 }\end{array}$ \\
\hline 16 & 安全防護物 & Safeguard & ガード又は安全装置 \\
\hline 17 & ガード & Guard & （人を）保護するために機械の一部として設計された物理的なバリア \\
\hline 18 & 保護装置 & Protective device & ガード以外の安全防護物 \\
\hline
\end{tabular}


表3＼cjkstart機械安全に関連した代表的なEU指令

\begin{tabular}{|c|c|c|c|}
\hline \multicolumn{2}{|r|}{ 名 称 } & 指令番号 & 内 容 \\
\hline 1 & 機械 & 2006/42/EC & $\begin{array}{l}\text { 表 } 2 \text { に定義した”機械”及び本指令の付属書 } \mathrm{V} \text { に規定された”安全部品”(人 } \\
\text { 体検知用の安全装置, 安全機能を実現する論理ユニットなど) を対象とし } \\
\text { た指令. 機械指令 } 98 / 37 / \mathrm{EC} \text { を改変した指令であり, 原則として } 2009 \text { 年 } \\
12 \text { 月 } 29 \text { 日より発効. }\end{array}$ \\
\hline 2 & $\begin{array}{l}\text { 電磁両立性 } \\
(\mathrm{EMC})\end{array}$ & 2014/30/EU & $\begin{array}{l}\text { 電磁妨害を引き起こす要因となる機器, 及び電磁妨害により影響を受ける } \\
\text { 機器を対象とした指令. }\end{array}$ \\
\hline 3 & 低電圧 (LV) & 2014/35/EU & $\begin{array}{l}\text { 入出力の定格電圧が AC50-1000V，又は DC75-1500V の範囲で使用され } \\
\text { るように設計をした電気製品を対象とした指令. }\end{array}$ \\
\hline
\end{tabular}

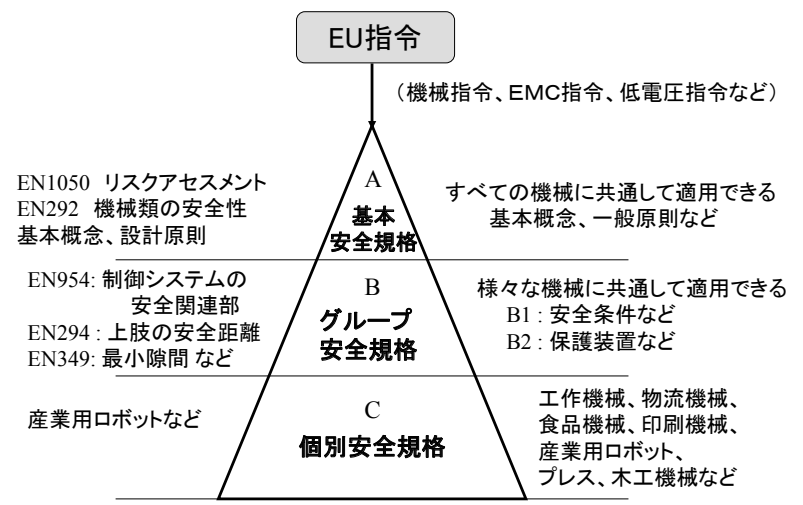

図 1 EN 規格の体系

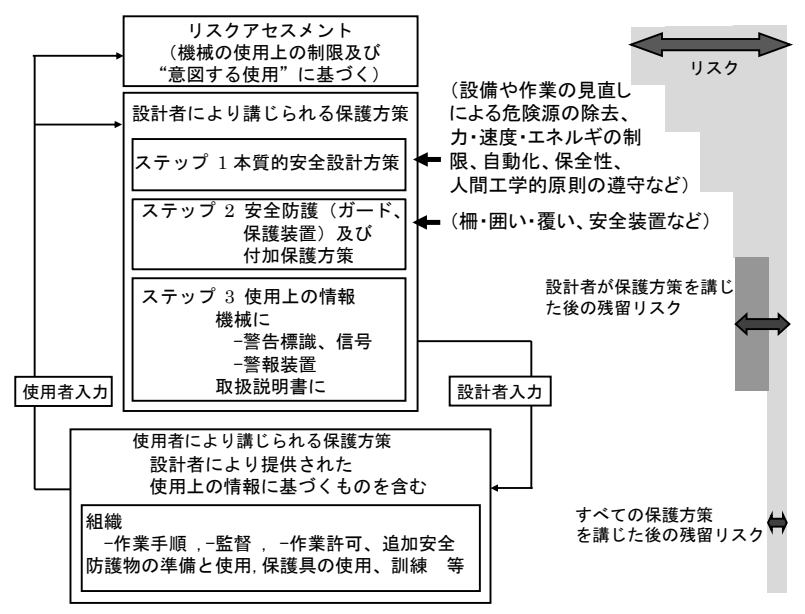

図 2 ISO12100 のリスク低減戦略

しかし，元々 EEC はイギリス，ドイツ，フランスの ように膨大な工業規格を持つ国々の共同体であり，これ らの規格の数は総計すると数万にも及ぶことから，この 整合化は遅々として進まなかった。

1985 年に, EC は上記のような状況を改善するため に, 従来の “オールド・アプローチ”に代わるものとし て“ニュー・アプローチ”という新しい政策を発表した. この特徴は, 従来の各国の国内規格に代わるものとして, 欧州閣僚理事会が EU 指令と称する安全に関する指令を 発令し，この指令に定める必須要求事項を製品が満足し ている限り，欧州連合（EU）内での製品の自由な流通を 認めるものである。このうち，機械安全に関する代表的 な EU 指令として機械指令, EMC 指令, 低電圧指令が ある (表 3 参照).

EU 指令は製品が絶対に達成しなければならない必須

Vol. 8, No.1, pp.13-27, (2015)
要求事項を示したものであり，詳細な技術上の要件を含 んでいない。 そこで，EUでは指令とは別に詳細な技術 上の要件を示した仕様書を作成し，指令を補完すること にした。これが欧州規格（EN 規格）である。

図 1 に, 機械指令に関連する EN 規格の体系図を示す. この規格は, 図 1 に示すようにタイプ A (基本安全規格), タイプ B (グループ安全規格), タイプ C（個別安全規格） という体系的な構成となっている。なお， EN 規格への 適合は強制ではないが，EN 規格に適合していれば $\mathrm{EU}$ 指令の必須要求事項に適合しているとみなされるため, 実際には EN 規格に適合するように製品を作らざるを得 ないのが現状である.

\section{2）機械のリスク低減戦略}

次に, EN 規格の中でも特に重要な規格として, 機械 のリスク低減戦略を定めた EN292 の技術的内容を概説 する.

現在，EN292 は機械安全国際規格 ISO12100（機械 類の安全性一設計の一般原則一リスクアセスメント及び リスク低減）:2010として標準化されている. 本節では, この規格に定められたリスク低減の進め方の概略を述べ る (図 2 参照).

具体的には，次の手順にしたがってリスク低減策を実

1）鋭利な端部，角，突起物などを除去する.

2）挟まれるおそれのある部分は，人体が進入でき ないように狭くするか，または挟まれるおそれが ない程度に広くする。

3）機械の可動部が発生する力を小さくする.

4）可動部の運転速度を小さくする.

5）可動部の持つ運動エネルギを小さくする.

6）応力の制限，過負荷の防止，破損や腐食の防止 などに配慮する。

7）設備の見直しやレイアウトの変更によって，危 険な設備を根絶する。

8）作業方法の変更によって, 危険な作業を根絶する.

9）自動化によって，人と機械の接触危険性を減少 させる。

10）有害性のない材料を使う.

11）転倒防止のために安定性を確保する.

12）ライン内の視認性を確保する.

13）誤操作しにくい配置や色とする など 


\begin{tabular}{|c|c|c|c|c|c|c|c|c|}
\hline \multirow{3}{*}{ 設計段階の } & A（内部生产管理） & \multirow{2}{*}{$\begin{array}{l}\text { A a （EＵ公認機関 } \\
\text { が製造者を補佐する } \\
\text { 内部生産管理） }\end{array}$} & \multicolumn{4}{|c|}{ B（型式試験） } & G（ユニットの検定） & H（全体の品質管理） \\
\hline & \multirow{4}{*}{ 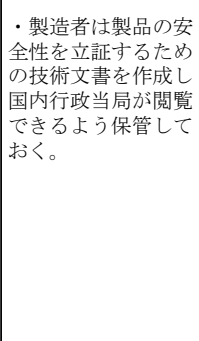 } & & \multirow{3}{*}{\multicolumn{4}{|c|}{ 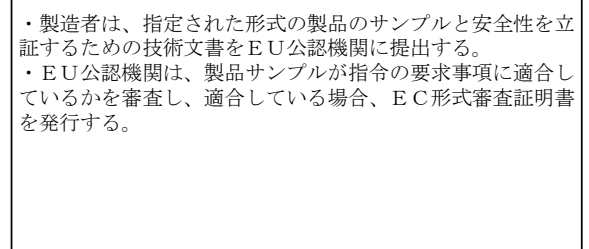 }} & \multirow{4}{*}{$\begin{array}{l}\text { ・製造者は製品の安 } \\
\text { 全性を立証するため } \\
\text { の技術文を書を E U公 } \\
\text { 䛱機関に提出する。 }\end{array}$} & \multirow{4}{*}{ 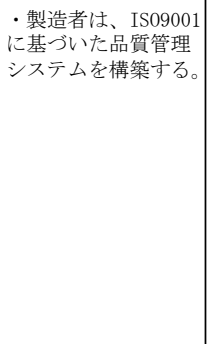 } \\
\hline & & \multirow{3}{*}{ 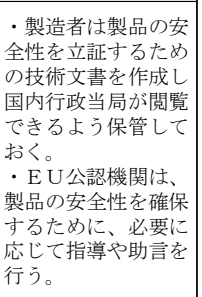 } & & & & & & \\
\hline & & & & & & & & \\
\hline & & & & & & & & \\
\hline \multirow{3}{*}{ 製造段階の } & \multirow{3}{*}{$\begin{array}{l}\text { 製造者は、必須要 } \\
\text { 氺事項への適合を宜 } \\
\text { 言すととともに、 } \\
\text { CEマーキングを行 } \\
\text { う。 }\end{array}$} & \multirow{3}{*}{ 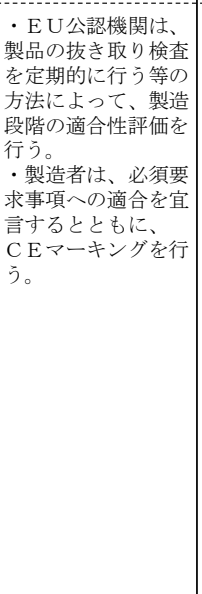 } & & & & & \multirow{3}{*}{ 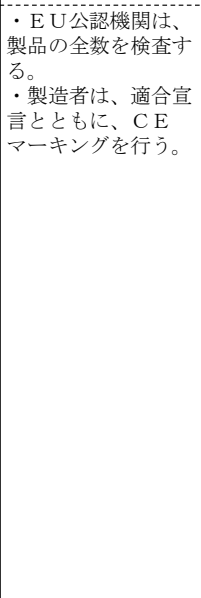 } & \multirow{3}{*}{$\begin{array}{l}\text { ISO0001に基づいて製 } \\
\text { 造者を監視する。 } \\
\text { 製造者は、適合宣 } \\
\text { 言とともに、C } \\
\text { マーキングを行う。 }\end{array}$} \\
\hline & & & $\begin{array}{l}\text { C (型式一の) } \\
\text { 適合性) }\end{array}$ & $\begin{array}{l}\mathrm{D} \text { (生产の品 } \\
\text { 質保証) }\end{array}$ & $\begin{array}{l}\mathrm{E} \text { 製品の品 } \\
\text { 質保証) }\end{array}$ & $\begin{array}{l}\mathrm{F} \text { (製品の検 } \\
\text { 定) }\end{array}$ & & \\
\hline & & & 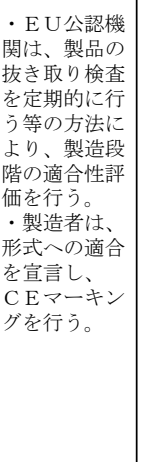 & 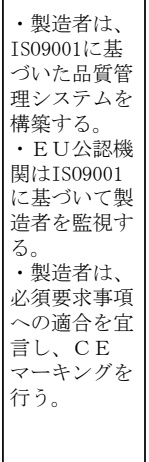 & 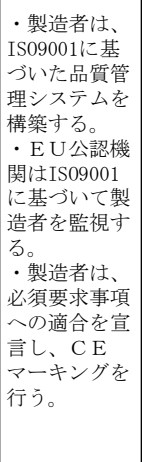 & 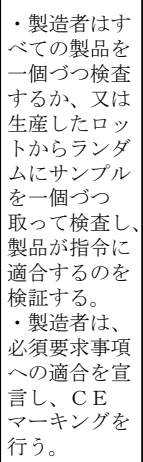 & & \\
\hline
\end{tabular}

図4 モジュール方式による適合性評価

施する.

（a）機械の意図する使用及び各種制限を明確にする.

(b) 機械を使用する作業等における種々の危険源（傷害 または健康障害を引き起こす潜在的根源），および関 連する危険状態（人が少なくとも 1 つの危険源に暴露 される状況）を同定する.

(c) 同定されたそれぞれの危険源，および危険状態に対し てリスクを見積もる.

（d）リスクを評価し，リスク低減の必要性を判断する.

(e) 本質的安全設計方策（図 3 参照）によって危険源を 除去またはリスクを低減する。これは, 図 2 のステッ プ 1 が該当する.

(f) ステップ 1 ではリスク低減が十分に達成できない場 合，安全防護および付加保護方策によってリスクを低 減させる，この方策は，図 2 のステップ 2 が該当する. ここで，安全防護には固定式ガードやインタロック式 ガードなどのガード，光線式安全装置や両手操作式制 御装置などの保護装置（安全装置）の設置などが含ま れる。 また，付加保護方策には非常停止ボタンの設置 などが含まれる。

(g) ステップ 1 と 2 でリスクを十分に低減できない場合, 警報装置や標識などによって危険を警告することや, 取扱説明書で機械の正しい使用法や保護具の使用を指 示することで，使用者側に機械の使用段階でのリスク 低減を委衫る。これは図 2 のステップ 3 が該当する.

(h) 機械の使用者は, ステップ 3 を受けて, 安全管理体 制の構築, 作業標準の作成, 保護具の使用, 教育・訓 練などを行う. （i）最終的に適切なリスク低減を達成できたと判断したと きに，リスク低減プロセスを終了する.

以上のようにステップ 1,2,3の各段階を経てリスク低 減を図る手法を 3 ステップメソッドと呼んでいる（補足 1 参照).

\section{3）モジュール方式による適合性評価}

実際の機械安全の実務では, 製品が EU 指令や EN 規 格に適合していることを評価する仕組みが必要である. この適合性評価のために, モジュール方式という手法を 採用する.

モジュールは, 図 4 に示すように $\mathrm{A}$ から $\mathrm{H}$ までの 8 種類が用意されている。このうち, モジュール A は危険 性の低い製品を対象としたもので，欧州で流通している 製品の 8 割程度を目安としている.

モジュール A では，製造者は製品が EU 指令に適合し ていることを自ら評価し，宣言する（適合宣言という）. ただし，実際には製造者自らが安全性を評価するのは困 難なときがある、そこで，第三者認証機関などの $\mathrm{EU}$ 公 認機関の力を借りて安全性を評価する。これが図 4 の Aa というモジュールである。ただし，モジュール Aa で EU 公認機関の力を借りても, 製品に起因して災害が発生し た場合，その責任は製造者にあるとされている.

これに対し，残り 2 割の危険性の高い製品は設計・試 作の段階で EU 公認機関による型式認定を取得する必要 がある。これが図 4 に示すモジュール B で, その型式認 定を基に製品を製造する際の適合性評価の方法としてモ ジュール C から F までが用意されている，例えば，機械 指令ではプレス機械, 成形機, 丸のこ, 帯のこなどの機 
械や人体検知用の安全装置などが該当する。これらのモ ジュールでは, 設計上の適合性評価を EU 公認機関が実 施する。このとき， EU 公認機関にも責任が生じる.

\section{4）自己責任に基づく適合宣言と CE マーキング}

適合性が評価された製品に対しては，製造者が自己責 任に基づいて適合宣言書を作成するとともに“CE” のマ ークを貼付する。これを $\mathrm{CE}$ マーキングという.

$\mathrm{CE}$ マーキングは製品が $\mathrm{EU}$ 指令を満足していること を製造者自らが評価し適合宣言するもので，既存のマー ク類のような検查機関の固有表示とは明確に異なる。こ の点に EU 固有の自己責任原則が貫かれている.なお, EUでは「マーク」を検查機関などの固有表示,「マーキ ング」を自己責任原則に基づく適合宣言を意味するもの として，両者を区別している.

また，モジュールによっては安全性の評価に EU 公認 機関が関与することもある。しかし，このときの適合宣 言も最終的には製造者の責任で行われる。したがって, 自己責任の原則を排除するものではないと考えられてい る.

\section{3 日本の現場力及び欧州の機械安全に関する調査分析 結果}

\section{1）調查対象}

本稿では以上の知見を前提とした上で，日本の現場力 及び欧州の機械安全に関する法規制及び社会制度の実態 を調査した．このときの “欧州”には，欧州連合（EU） に加盟するイギリス，ドイツ，フランス，イタリアなど 28 か国と，EUに加盟していないスイス及びノルウェー を含めた。

ただし，機械安全に関する法規制，社会制度，及び具 体的な機械安全技術などはイギリス，ドイツ，フランス が中心となって発展してきた経緯がある。そこで，これ らの 3 か国を重点的に調查した。

一方で，本稿では，日本の “現場力”の活用や筆者ら が提案している “根拠に基づく安全理論”（EBS:theory of Evidence-Based Safety）を活用するという観点からの 検討も必要である。 そこで, 次のような項目を対象に調 査分析を行った。

（a）日本の “現場力”の源泉である安全管理活動及び生産 技術などの調査

（b）欧州機械安全の基本理念と災害防止原則の抽出

(c) 労働安全衛生法等に反映できる可能性がある欧州の機 械安全規格，法規制及び安全技術の調査と分析

（d）日本の制度に反映できる可能性がある欧州の適合性 評価制度とマーキング制度の調査と分析

(e) 欧州での労働災害発生状況に関するデータの調査と 当該データに基づく機械指令等の有効性評価

(f) 機械の使用段階における妥当性確認の有効性検証

(g) 筆者らが提唱している “根拠に基づく安全理論”の活 用方策

（h）その他，日本の法規制や社会制度に反映できる機能 安全・電気安全・材料安全・システム安全などに関す

\section{る技術や制度の調查}

以上のうち，本稿では他の研究ではほとんど検討され ていない a),b) 及びf) を対象に重点的に考察を行う.なお, 日本の現場力の調查と分析にあたっては文献 5)～13）の 記載を参考にした。また，“根拠に基づく安全理論”は別 途，稿を改めて報告を行う予定でいる.

\section{2）日本の“現場力”に基づく安全管理と生産技術の調査 及び分析結果}

\section{（1）現場力の定義}

“現場力”という用語は，実務の場で頻繁に使用される 用語であるが，多くの場合，定義を不明確としたまま使 用されているのが現状である。このため, 本稿では最初 に“現場力”という用語の定義の明確化を試みた.

この検討を学術的観点から実施した唯一ともいえる例 に，経営学の専門家である遠藤功が “現場力の教科書” 5) の中で試みた規定がある。この著書で，遠藤は現場力を “経営戦略を現場に落とし込み，実行寸る組織能力” 5) と 規定している。このため，本稿では，この遠藤の規定を 考慮した上で“現場力”を次のように定義した.

“経営者が定めた経営戦略を達成するために，作業者や 管理・監督者及び生産技術者などが現場の実情に応じた 適切な解決策を組織的に提案し実行する能力”

なお，ここでいう解決策の中では，安全・品質・環境 の確保, 生産性の改善, 原価の低減, 納期の遵守などが 特に重要と考えられる ${ }^{6)}$.

\section{（2）安全管理に対するパラダイム転換}

前述した現場力を利用して働く人の安全を確保する活 動が，現場力に基づく安全管理である。このような安全 管理は多くの場合，コスト要因と理解されている。しか し，現場力の高い企業が安全管理に適切に取り組むこと によって生産性や保全性なども改善し，コスト削減に繋 がった例もある ${ }^{7-9)}$ (これらの具体例は後述する (5) の事 例を参照のこと).

このように，安全性と生産性の両立など，通常では相 反し両立が困難と考えられる課題を現場力の活用によっ て高次の次元で融合させ，解決に導けることがある。こ のとき, 現場の安全管理を担う関係者にとって “安全は コストでなく，新たな価值を創造するための投資”と位 置づけられる，なお，現場の安全管理を担う関係者とは 図 5 に示寸企業の経営者, 機械の設計・製造者, 現場の 作業者や管理・監督者及び生産技術者などが考えられる。 また，ここで言う価值には働く人の安全は当然として, 品質・環境の改善や生産性・作業性・保全性の改善によっ て得られる企業の競争力強化など ${ }^{10)}$ も含まれる.

本稿で述べる現場力に基づく安全管理は，安全をコス トでなく新たな価值創造のための投資として位置づける というパラダイム転換を目指寸ものである。このパラダ イム転換では，前述した現場の安全管理を担う関係者の 意識や価值観の転換が特に重要なポイントとなる。この 転換の推進力となるのが，現場における高い当事者意識 11) と安全な職場を構築しようとする共通の価值観 ${ }^{5)}$ と考 えられる。

Vol. 8, No.1, pp.13-27, (2015) 
現在，各企業では労働災害防止のために情報の共有が 求められている。しかし，単に IT 機器などを利用して膨 大な情報の共有を図るだけでは不十分で，高い当事者意 識と安全な職場を構築しようとする共通の価值観を関係 者間で共有し実践する仕組みと戦略が，今後の安全管理 では不可欠と考えられる。この点は今後の検討課題であ るが，現段階で想定できる事項を(3) 及び (4) に示した.

\section{（3）安全管理で望まれる経営戦略}

現場力に基づく安全管理では，実際の現場を担う作業 者や管理・監督者だけでなく, 経営戦略を定める経営者, 及び現場力改善のポイントとなる機械の設計・製造者や 生産技術者の役割も大変重要である. これらの関係者が 図 $5^{5)}$ に示すように各々の役割を適切に果たすことによっ て，安全管理に関する現場力の強化が図られる.

この点で, 経営者が安全管理に関する適切な経営戦略 を策定することは，実効性のある安全管理活動を展開す る上で重要な意義がある。しかし, 企業の中には, 経営 者が安全管理に関する明確な経営戦略を示すことなく, 現場力強化のためと称して多くの手法やッールを漫然と 試みる企業も散見される.

このように漫然と多くの手法やツールを試みる姿勢は 現場にとって過大な負担となるだけでなく，時として混 乱を招くこともある．むしろ，筆者らは，数多くの手法 やツールに取り組むよりは, 少数の安全管理に関する経 営戦略を厳選し，その徹底を図った方が高い災害防止効 果が得られると考える.

なお，安全管理に関する経営戦略は，各企業の実情に 応じて当然に異なったものとなる. 一方で, 戦略の策定 にあたっては当然に留意すべき事項が存在する，筆者ら は，この留意事項として，(1)再発防止から未然防止への 戦略転換, (2)件数重視から重篤度重視への戦略転換, (3) 想定外の考慮などを提案している ${ }^{14)}$.

（4）安全管理に必要な集合知を構築し実践する仕組み

実際の安全管理では, 関係者間の協力と連携によって, 現場で発生する可能性がある問題をあらかじめ予測して 組織的に解決するための実践的な知識体系が不可欠であ る.このような体系の構築にあたっては個人の努力も重

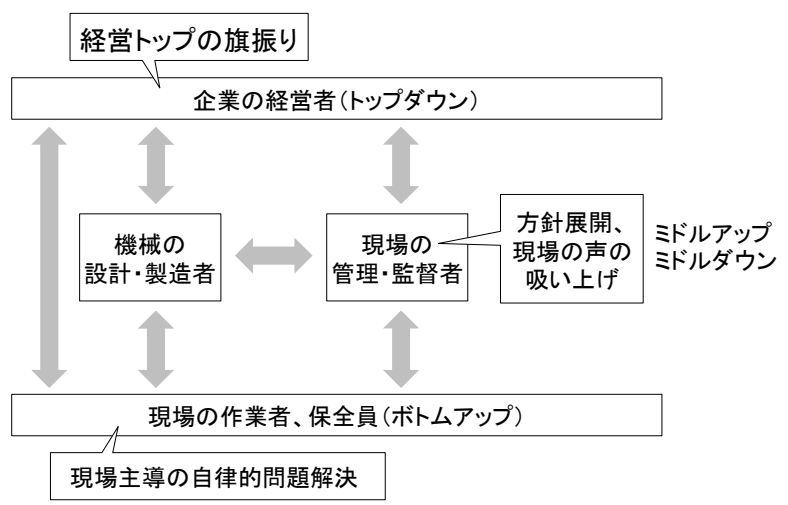

（出典） 遠藤功, 現場力の教科書, 光文社新書 (2012) p.112 の図を基に一部を追記して作成

図 5 現場力強化のための各担当者の役割 ${ }^{5)}$
要であるが，チームで取り組むことによってお互いが刺 激し合い, アイデアの連鎖が生まれるとされている ${ }^{5}$.

このようなプロセスを経て獲得された知識の体系を本 稿では “集合知”と呼ぶことにする，この体系的な集合 知の構築が, 日本の現場における質の高い安全管理を可 能にしていると考えられる. ただし, 集合知の構築にあ たっては，一部の人だけでなく現場のすべての関係者が 独立した個人として知識体系の構築に積極的に取り組む 必要がある ${ }^{5)}$. この点が保証されないと, 現場力を基に 新たな価值創造を図るのは大変困難となる.

表 4 に, 現場力に基づく安全管理の集合知の体系を示 す.この表の基本理念の作成にあたっては, 筆者らの研 究成果と古澤登の文献 8) を参考にした。この文献では, 自動車製造業における安全管理活動の実践の中で, “人づ くりが安全風土をつくり, 企業を成長させる”, “ある心゙ き姿の設定と見える化・共有化・具体化”, “的を絞った 活動の大切さ”, “人がモノをつくるのだから，人をつく らねば仕事も始まらない”など, 現場力に基づく安全管 理の基本理念が述べられている.

また，この表の具体的技術の作成にあたっては，遠藤 功の文献 5),11）だけでなく, 中村昌充の文献 12) 及び公 益財団法人労働科学研究所が発行している「労働の科学」 での “現場力を築く”という特集号 ${ }^{13)}$ なども参考にした。

ここで重要なのが, 遠藤功が文献 5) で現場力を生み出 寸ために欠かせない要素として指摘している図 $6^{5)}$ 及び 図 $7^{5)}$ の関係図である。これらの図は，現場力の基盤と なるのが共通の価值観＝基本理念であることを示してい る.この点を理解しないで単に手法やツールに重点を置

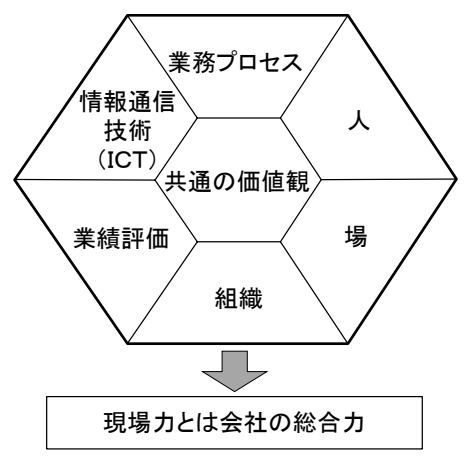

（出典） 遠藤功, 現場力の教科書, 光文社新書 (2012) p.206

図 6 強い現場力を支える共通の価值観 ${ }^{5)}$

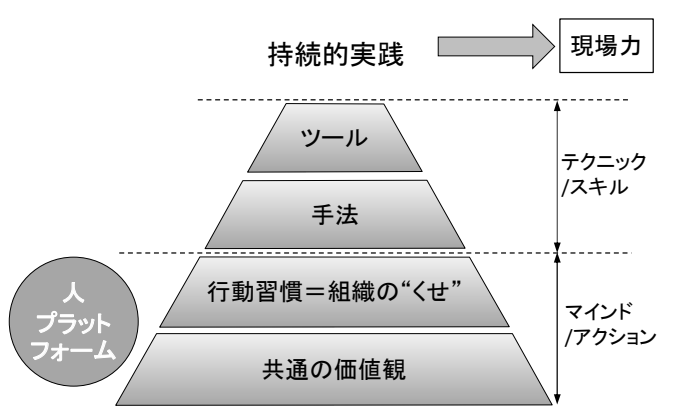

（出典） 遠藤功, 現場力の教科書, 光文社新書 (2012) p.126

図 7 強い現場力を支える階層構造 ${ }^{5}$ 
いて安全管理を進めると, 安全管理の形骸化が進行し, 現場力の成果である集合知に基づいて安全管理を継続的 に実践するのは大変難しくなる.

\section{（5）生産技術の活用による安全性と生産性の両立}

次に, “現場力”のもう一つの基盤である生産技術の活 用によって, 安全性と生産性の両立を達成する方法を考 察する．このときに活用できる生産技術が，第 2 章の 2) で述べた本質的安全設計方策（図 3 参照）である.

具体的には，“生産システムの抜本的見直しによる危険 な設備や作業の根絶”, “力やエネルギの制限による低推 力化”, “機械の信頼度の改善によって人が危険区域に進 入寸る頻度の減少”, “危険区域の外からの点検や保全の 実施”などの本質的安全設計方策によって労働災害の発 生を防止する方策が該当する。

また, 安全性と生産性の両立にあたって注目す心゙き事
例に, 表 4 の項番 6 に示した設備改善活動がある ${ }^{7-9)}$. こ のうち, 文献 8) の古澤らの活動では，ガードや保護装置 (安全装置) が取り付けられている設備を対象に, 敢えて ガードや安全装置を取り払った状態を作り出して対策を 検討している。このようにすれば，現場は保護装置を取 り付けるという対策に代えて，生産技術に基づく本質的 安全設計方策という観点から抜本的な保護方策を採用せ ざるを得ない。

これにより，ガードや保護装置が取り付けられていた ときには潜在していた問題が顕在化するために，安全技 術の高度化（図 2 のステップ 2 からステップ 1 への改善） とともに，生産ラインのシンプル化とスリム化が図れる.

この具体例として, 古澤らは, 文献 8) で部品加工用の 自動ラインに適用された昇降リフターや搬送機の例を挙 げている，当初，これらの設備に対してはガードや保護

表4 現場力に基づく安全管理の集合知の体系

\begin{tabular}{|c|c|c|c|c|}
\hline \multicolumn{2}{|c|}{ 大分類 } & 中分類 & 小分類 & 説明または具体例 \\
\hline 1 & \multicolumn{2}{|c|}{ 基本理念 } & $\begin{array}{l}\text { 高い当事者意識と関係者 } \\
\text { 間の連携のに安全な職 } \\
\text { 場を構築しょうとする共 } \\
\text { 通の価值観 }\end{array}$ & 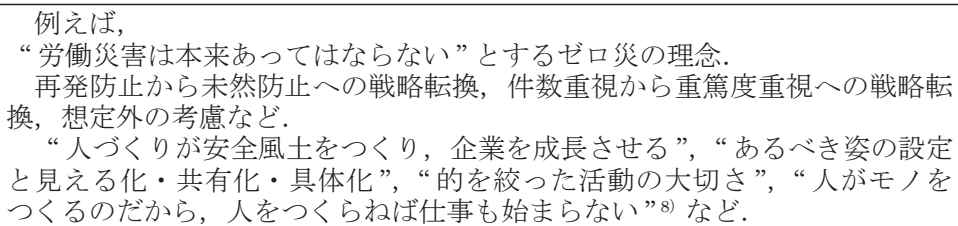 \\
\hline 2 & \multirow{10}{*}{$\begin{array}{l}\text { 具 } \\
\text { 体 } \\
\text { 的 } \\
\text { 技 }\end{array}$} & \multirow[t]{5}{*}{ 設備の安全化 } & 本質的安全設計方策 & $\begin{array}{l}\text { 設備や作業の見直しによる危険源の除去, 力・速度・エネルギの制限, 自 } \\
\text { 動化, 保全性改善, 人間工学的原則の遵守など. 現場力を適切に発揮させる } \\
\text { 際の前提となる術である. }\end{array}$ \\
\hline 3 & & & $\begin{array}{l}\text { 安全防護（ガードまたは } \\
\text { 保護装置） }\end{array}$ & $\begin{array}{l}\text { 柵・囲い・覆いなどの固定式ガード, 扉インタロックなどの可動式ガード, } \\
\text { 光線式安全囬, レーザー式安全装置, 両手操作式安全装置など. 現場力を } \\
\text { 適切に発揮させる際の前提となる技術である. }\end{array}$ \\
\hline 4 & & & 安全確認形インタロック & 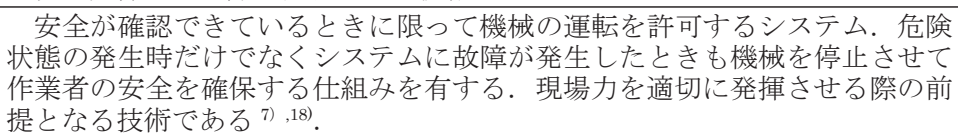 \\
\hline 5 & & & $\begin{array}{l}\text { 異種㝋長化と自動監視 (セ } \\
\text { ルチェック) }\end{array}$ & $\begin{array}{c}\text { 異種圥長化と自動監視技術の併用によって, 制御システムの安全関連部の } \\
\text { 危険側故障の発生確率を可能な限り減少させる. }\end{array}$ \\
\hline 6 & & & $\begin{array}{l}\text { 安全技術と生産技術の併 } \\
\text { 用による安全性と生産性 } \\
\text { 等の両立 }\end{array}$ & 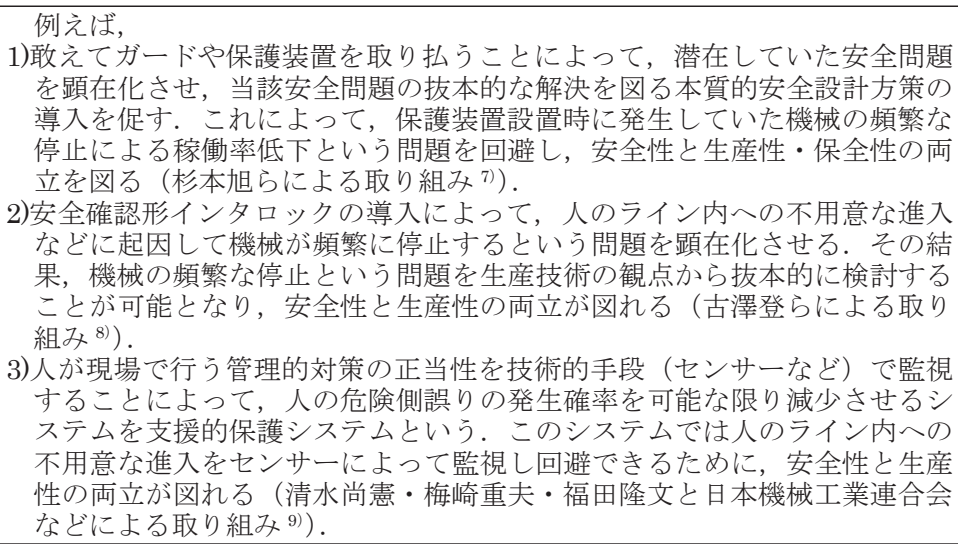 \\
\hline 7 & & 作業の標準化 & 作業標準の策定 & $\begin{array}{l}\text { 定常作業や想定される非定常作業に対して，想定されるリスク及びその対 } \\
\text { 策を明記した安全作業マニュアル作成する }{ }^{13)} .\end{array}$ \\
\hline 8 & & 技能・安全教育 & $\begin{array}{l}\text { 技能教育 } \\
\text { 安全に関する教育・訓練 }\end{array}$ & $\begin{array}{l}\text { 作業標準のない非定常作業や突登作業（夜間・休日作業を含む）に対して, } \\
\text { 管理・監督者が不在でも作業者が適切に判断して対応できるうに技能教育 } \\
\text { や安全に関する教育・訓練を強化する. }\end{array}$ \\
\hline 9 & & \multirow[t]{3}{*}{ 管理 } & 管理者のリーダーシップ & 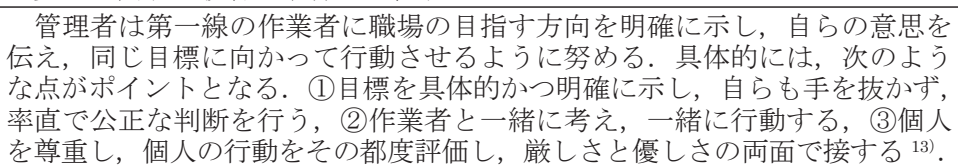 \\
\hline 10 & & & 個人の育成と承認 & $\begin{array}{l}\text { 様々な個人の個性と独自性を尊重し, それぞれの人の特性に見合った最適 } \\
\text { な割を認め, その存在を承認する). }\end{array}$ \\
\hline 11 & & & 正しい個人評価 & $\begin{array}{l}\text { 安全に取り組む人が正当に評価され，かつ全員に対してその評価が広く周 } \\
\text { 知される仕組みを構築する }{ }^{13)} \text {. }\end{array}$ \\
\hline
\end{tabular}

Vol. 8, No.1, pp.13-27, (2015) 
表5＼cjkstart機械安全と安全管理の基本理念と災害防止原則の比較 ${ }^{15)}$

\begin{tabular}{|c|c|c|c|}
\hline 离 & 欧州の機械安全技術と社会制度 & 日本の伝統的な安全管理 & $\begin{array}{l}\text { (参考) 労働安全衛生マネジメン } \\
\text { トシステム }\end{array}$ \\
\hline $\begin{array}{l}\text { 基 } \\
\text { 本 } \\
\text { 理 } \\
\text { 念 }\end{array}$ & 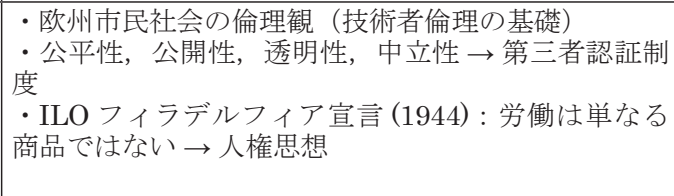 & $\begin{array}{l}\text { ・労働災害は本来あってはならない } \\
\rightarrow \text { セ炎の理念 }\end{array}$ & \multirow[t]{2}{*}{$\begin{array}{l}\text { ・企業トップのリーダーシップ } \\
\text { に基づく安全文化の育成 } \\
\text { 関係者全員が“安全な企業を } \\
\text { 作りたい”学 } \\
\text { ・労働安全衛生マネ価值観の共有 } \\
\text { ステム構築によるシスン } \\
\text { 続的改善 }\end{array}$} \\
\hline 原 & 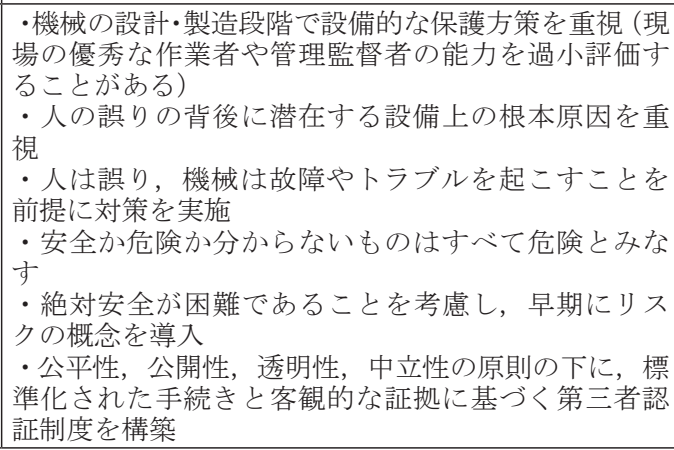 & $\begin{array}{l}\text { ・機械の使用段階での管理的対策を } \\
\text { 重視 (現場の優な秀な作業者や管理監 } \\
\text { 督者の技能に期待) } \\
\text { •㷋害の原因をの誤りと捉え, 教育・ } \\
\text { 訓練で問題解決能力を強化 } \\
\text { ・「労働災害は本来あってはならない } \\
\text { とするゼロ災の理念が強い } \\
\text { ・能力が高い専門家の判断を優先す } \\
\text { るが, 属人的な要素が強い }\end{array}$ & \\
\hline
\end{tabular}

（出典）梅崎重夫・濱島京子・清水尚憲, 機械安全と安全管理における基本理念と災害防止原則の比較 一ベスト・プラクティスの観点からー, 労働科学, Vol.86, No.4 (2010) p.219を基に作成

装置を取り付けていたが，設備の故障やトラブルに伴う 機械の停止も多く，その処置時に災害も発生していた。 そこで，ガードや保護装置（図 2 のステップ 2) に代え て危険源の除去を目的とした本質的安全設計方策（図 2 のステップ 1）を採用した。具体的には，リフターをな くすとともに，搬送機などの低推力化を進めた。結果と して，ライン停止が少なくなり保全性が向上するととも に，けがをする機会も減少し，生産性もアップしたとの ことである。

以上のように，本質的安全設計方策ではライン停止の 影響を少なくできるために，安全性とともに生産性や保 全性の改善を図ることができる，したがって，日本の強 みである生産技術の活用によってステップ 1 の本質的安 全設計方策を生産ラインに適切に活用していけば，安全 性だけでなく生産性や保全性の改善も図ることができ, 日本の国際競争力の強化に貢献できると考えられる.

\section{3）欧州の機械安全に関する基本理念と災害防止原則の 抽出結果}

以上の現場力を基盤に置いた上で，安全の先進国と言 われる欧州の機械安全技術や社会制度を適切に活用寸れ ば, 日本の現場力と欧州の機械安全技術を高次の次元で 融合させた新しい枠組みの安全技術と社会制度を構築で きる可能性がある。ただし，このためには欧州の機械安 全の根幹に暗黙知として存在する基本理念と災害防止原 則を抽出し，経営者や設計者を始めとする関係者がその 本質を確実に習得する必要がある。

この点は筆者らが既に文献 15) で考察しているが，現 段階の知見も踏まえて改めて抽出を試みた.

\section{（1）基本理念の比較}

これまでの日本では，現場の優秀な作業者や管理・監 督者の技能と注意力に依存して労働災害を防止するとい う手法が一般的であった。 しかし，人の技能と注意力に 依存した対策には明らかに限界がある。
これに対し，欧州では“人は誤り，機械は故障やトラ ブルを起こす”ことを前提に機械安全技術を作り上げて きた。また，これらの技術を体系的な欧州安全規格（EN 規格）としてまとめ上げ，広く普及可能なものとした。

さらに，これらの技術の背後にある設計思想を西欧市 民社会の倫理観（技術者倫理の基礎となる社会常識）と 融合させ，社会制度化することに成功した。この具体例 に，前述した CE マーキング制度や第三者認証制度など がある。ちなみに，リスクの概念や製造物責任，公平性， 公開性，透明性，公正・中立性などの考え方は，西欧市 民社会の根底にある倫理観（技術者倫理の基礎となる社 会常識）を習得しなければ，その本質が理解できないと 考えられる.いずれにしても, これらの財産を総動員し て安全を確固たる社会制度として構築したところに，安 全の先進国である欧州の特徵がある.

また，ILO を先導した欧米諸国では，そのフィラデル フィア宣言の付属書 ${ }^{16)}$ の記載からも分かるように，安全 を“人権”という観点から捉える傾向が強かったと考え られる。これに対し，かつての日本では，小田川全之や 蒲生俊文などの安全活動に熱心な啓蒙的な指導者が “労 働災害は本来あってはならない”というゼロ災の理念に 基づいて労働災害防止対策を指導するという形態が一般 的であった。

この違いが何に起因するかについては，安全文化との 関係などから様々な説明が示されている（たとえば，狩 猟民族と農耕民族の違いや ${ }^{17)}$ ， 日本では西欧のような市 民革命を経ていない点に根拠を求める意見もある。また， 西欧では“人の誤り”（過失）や“人による保護装置の意 図的な無効化” (故意) などは起こり得るという性悪説の 観点から保護方策を実施するのに対し，日本では性善説 の立場に立って人の善意に依存する管理的対策を進める ためという見解もある)。しかし，国境を越えて人や物が 頻繁に移動し，これに伴う問題に絶えず晒されていた欧 
州では, “安全は自ら勝ち取るもの”という意識がなけれ ば, とても自らの生存の確保は困難であっただろう。

これに対し，島国で農耕を中心とする生活を営んでい たかつての日本では, 安全は啓蒙的な指導者が上から与 えるものという傾向も強かったように思える。このよう な社会では, “和を以て貴しとなす”という言葉に端的に 表れているように，実際の労働災害防止対策は“現場の 優秀な作業者や管理・監督者が，他の関係者と協調しな がら安全管理活動を継続的に改善して行く”という管理 的対策が中心となっていったと考えられる.

表 5 に, 以上のような背景の下で培われた安全に関す る欧州と日本の基本理念の特徴を示す，表からも明らか なように, 機械安全の基本理念では, 欧州の場合は “倫理” と“制度”が特に重要である.

これに対し，安全管理の基本理念では，欧米諸国では “安全は自ら勝ち取るもの”という考え方が中心であるの に対して, 日本では“安全は上から与えられるもの” いう観点から，“他者との連携の下で現場力に基づく安全 管理活動を継続的に改善する”という考えが中心となっ ていったと考えられる.この違いが日本と欧米諸国の間 で安全に関する考え方に差異を生じる根本原因になった のではないだろうか.

なお，この点について，中村昌充は文献 12）で“日本 と欧米で技術開発を経験した期間の長さに違いがあった” ことが両者の違いを生んだ原因と指摘している. 中村に よれば，新しい技術の工業化過程では技術開発の不備に 基づくトラブルが必然的に発生する。しかし，欧米では ほとんどの技術を自らの手で開発して工業化したために 技術力で安全を確保するという考えが中心となった。

これに対し, 日本では開発過程でのトラブルが既に解 決された技術を欧米から導入することで発展してきたた めに, ルールを守ってきちんと生産すれば安全を確保で きるという考えとなった。この点が技術中心の欧米と人 による管理中心の日本という違いを生んだとしている. この指摘は, 日本と欧米での安全に関する基本理念の違 いを考察する際に重要なポイントと考えられる.

\section{(2) 災害防止原則の比較}

次に，欧州の機械安全に関する災害防止原則を文献 15）の記載を基に抽出する.

表 5 に, その抽出結果を示す. 表からも明らかなように, 欧州機械安全の災害防止原則では, “機械の設計, 製造段 階での対策を重視する”, “人は誤り，機械は故障やトラ ブルを起こすことを前提に対策を実施する”など， 日本 の現場力強化のために活用できる多くの暗黙知が認めら れた。これらは, 日本の現場の集合知とすることで, 安 全管理活動に活用できると考えられる.

ここで, 表中の “安全か危険か分からないものはす心゙ て危険とみなす”という原則は, 日本でも杉本旭・向殿 政男・蓬原弘一らが “安全の原理”18) として提唱していた ものである。これと同様の原則に，環境分野における予 防原則がある，また，品質の分野でも「良品か不良品か 分からないものは不良品と夕な寸」という考えが成り立
つ、したがって, このような考え方は, 品質・安全・環 境の各分野を横断する普遍的な考え方といえる.

以上の検討では, 現場力に基づいて安全管理活動を継 続的に改善して行くという日本の伝統的な安全管理を欧 州との比較の主たる対象とした。しかし, 近年, “現場力” と一体となった伝統的な安全管理が衰退する中で，これ を補完するものとして労㗢安全衛生マネジメントシステ ムが提唱されつつある。 そこで, 表 5 では労㗢安全衛生 マネジメントシステム ${ }^{17)}$ に含まれる暗黙知も含めて参考 として比較検討を行った.

\section{（3） 今後の安全管理への反映}

以上，日本と欧州での安全に関する基本理念と災害防 止原則の比較を行った．従来，このような比較を行う場 合は “進んだ欧州と遅れた日本”という観点から分析が 行われることが多かったと考えられる。これは日本の現 状を考慮すると部分的には正しい，したがって，現段階 では，経営者及び設計者を始めとする関係者に対して欧 州機械安全の基本理念と災害防止原則の普及促進を図る ことが最優先課題と考えられる.

一方で, 日本には後退が著しいとはいえ，現場力に基 づく質の高い安全管理と生産技術の力がある。したがっ て, 今後の日本の安全管理では, 現場力を基盤に置いた 上で欧州の機械安全技術や社会制度を適切に活用するこ とによって, 日本の現場力と欧州の機械安全技術を高次 の次元で融合させた新しい枠組みの安全技術と社会制度 へとスパイラルアップを図れる可能性がある.この検討 で重要となるのが，日本と欧州での安全に関する基本理 念と災害防止原則を共通の価值観として高次の次元で融 合させる作業である，以上のような方策が今後の日本に 残された数少ない戦略ではないだろうか.

\section{4）機械の使用段階の妥当性確認に関する調查結果}

第 2 章で述べた内容は，機械安全の専門家にとっては 既知の事項である。これに対し, 機械の使用段階で行う 妥当性確認は日本ではほとんど情報が得られていない， そこで, 適合性評価と妥当性確認の違いを考察するとと もに，ドイツ，フランス，及びイギリスでの実態調查を 基に，欧州の事業者及び政府関係機関が行う妥当性確認 の内容を重点的に調查した ${ }^{4}$.

\section{（1）適合性評価と妥当性確認}

規格は, 現時点での科学・技術及び経験に基づいて, 関係者のコンセンサスと承認の下に作成される。この規 格に適合しているか否かを判定する行為が “適合性評価” (conformity assessment) である。この用語は ISO/IEC 17000 に製品, プロセス, システム, 要員又は機関に 関する規定要求事項が満たされていることの実証」と定 義されている.

また，妥当性確認（Validation）とはISO9000に「客 観的証拠を提示することによって，特定の意図された用 途又は適用に関する要求事項が満たされていることを確 認すること」と定義されている.

製品安全の体系である欧州の機械安全規格では, 製品 が特定の安全規格に適合しているか否かを判定する行為

Vol. 8, No.1, pp.13-27, (2015) 
が重要である。これは前述した適合性評価に他ならない。 一方，労働安全分野では，機械の使用者が実際の機械の 使用にあたって労働災害が発生する可能性がないかを個 別具体的に確認する行為が特に重要となる，これは，労 働災害防止という特定の意図又は用途を対象に，個別の 機械が安全であるか否かの確認を個別具体的に行う行為 であり，前述した妥当性確認に相当する.

従来，欧州の機械安全に関する制度を日本に紹介する ときは，モジュール方式による適合性評価制度など，機 械の設計・製造段階での適合性評価が重視されていた。 しかし，労働災害防止という観点からは，機械の使用段 階で “労働災害が発生する可能性がないか”を個別具体 的に確認する妥当性確認にも留意する必要がある。この ときに使用できるのが，文献 14）の根拠に基づく安全理 論 $(\mathrm{EBS})$ で提案している“エビデンス”である。これは, 理論, 実績, データの 3 種類に類型化できる.

以上の観点から，機械の使用段階の妥当性確認を対象 に，ドイツ，フランス，及びイギリスで調査した結果を 次に述べる.

\section{（2）ドイツ及びフランスでの妥当性確認}

表 6 に，機械の使用段階での妥当性確認に対するドイ ツ及びフランスでの調査結果を示す．表からも明らかな ように，少なくともドイツとフランスでは機械の使用段 階での妥当性確認が政府機関等によって適切に実施され ており，これが機械に起因する労働災害の未然防止に大 変役立っていることが推察された.

例えば，フランスではリスクアセスメントを法令で義 務化し，かつ，機械・電気・化学・人間工学などの専門 的能力を備えた労働監督官による現場の監視・監督によっ て，現場における妥当性確認の実効性を高めているとの ことである (表 6 の質問事項(1)が該当)。この労働監督の 頻度は，労働者数が 50 名以上の企業は少なくとも 1 年 に 1 回, それ未満の小さい企業でも 3 年に 1 回は労働監 督官が監督を行うとのことである（表 6 の質問事項(3)）.

また，機械や化学などの個別の工学分野に対しては, その分野ごとの専門家が労働監督機関に配置されており， 監督官の技術的相談や事業場の指導などにあたっている とのことである（表 6 の質問事項(1)が該当）.

これに対し，ドイツでは(1)ドイツ各州の労働省の監督 官，(2)製品安全と製品の流通に対して監視・監督権限を 持つ行政流通監視評議会（GAA）の検查官，及び(3)ドイ ツで労災保険を運営する BG の検査員などの連携によっ て，機械の使用段階における妥当性確認を実施している とのことである（表 6 の質問事項(1)が該当).

要するに，フランスでは国が主体となって妥当性確認 を担っているのに対して，ドイツでは国，州及び保険会 社である BGの連携の下に妥当性確認を担っているとい う特徴がある。これらの活動と事業者側が行う自主対応 との連携によって実効性のある社会制度が構築されてい る。この点は，日本で望まれる社会制度を検討する際に 大変参考になると考えられる.

（3）イギリスでの妥当性確認
同様に，イギリスの調査結果で特に注目すべき点は, 労働監督官自身が相当に高いレベルの知識と現場の経験 を持って，現場の様々なニーズに的確に対応している点 であった。また彼らは HSL（イギリスの国立安全衛生研 究所）の研究員とも常に連携を取りながら, 最新の技術 情報に基づいた現場の安全指導を実施しており，HSLの 研究員も労働監督官からの要望に沿った研究テーマを研 究しているとのことであった.

日本でのリスクアセスメントの取り組みについては, イギリスの労働監督官及び HSL の研究員ともに熟知して いるようであった，その上での意見として，“日本のリス クアセスメントの手法はイギリスより緻密である。しか し，リスクの概念はイギリスの方が現場での普及が進ん でいる，日本はリスクアセスメントを非常に大事にして いるが，イギリスではリスクアセスメントは中小零細企 業がリスクの概念を習得してもらう際の教材に過ぎない. この点が日本とイギリスで大きく異なっている.”との指 摘を受けた。この点は, 今後, 日本でリスクアセスメン 卜を普及促進して行く上で重要な指摘と考えられる.

\section{4 考察}

本稿では, 現段階で想定できる機械安全に関する日本 での法規制案と社会制度案を複数設定し, 各提案を対象 に，災害防止効果の有効性や実現可能性及び問題点など の検証を行う。この提案には，例えば，(1)完全整合化案， (2)実質同一案，及び(3)従来の規制を徹底する案などが考 えられる。

以下, これらの案の現段階での概略と, 検証を行う際 に留意すべき事項や問題点を述べる.

\section{1）完全整合化案}

この案は, 日本の機械安全に関する法規制及び社会制 度を欧州の法規制や社会制度などと完全に整合させる案 である，具体的には，欧州機械指令に相当する “機械安 全法”を強制法規として定めるとともに, 体系的な機械 安全規格 (図 1 参照), 欧州方式の適合性評価制度（図 4 参照), 第三者認証制度及びマーキング制度を整備する案 などが考えられる。

この案では，機械安全法として，(1)欧州機械指令 の付属書, (2)イギリスの機械安全関係の規則である PUWER (The Provision and Use of Work Equipment Regulations), (3) ILO が 2011 年に主に途上国向けに機 械安全に関する要求事項をまとめた “Code of Practice on Safety and Health in the Use of Machinery”, (4) ILO 第 118 号勧告(機械の防護に関する勧告)などが参考になる.

また，体系的な機械安全規格として ISO/IEC 規格や $\mathrm{EN}$ 規格などに定められた内容が参考になる。さらに， 適合性評価とマーキングには欧州で実施されているモ ジュール方式の適合性評価（図 4 参照）や CE マーキン グ制度の採用などが考えられる。

この案の利点は, 製品の自由な流通が経済効果を生む という点にあると言われている。例えば, 近年, 安全技 術の国際化が急速に進展したことによって, 一部の有識 
表6 機械使用事業場での機械の妥当性確認に関する欧州ヒアリング調查結果 ${ }^{4)}$

\begin{tabular}{|c|c|c|}
\hline 質問事項 & $\begin{array}{l}\text { ドイツ回答 } \\
\end{array}$ & フランス回答 \\
\hline $\begin{array}{l}\text { (1)ユーザ事業場において使 } \\
\text { 用開始される又は使用さ } \\
\text { れている機械・設備に対 } \\
\text { して, 機械指令へ適合 } \\
\text { を検査 (妥当性確認) す } \\
\text { る公的な制度・仕組みが } \\
\text { あるか. 制度がある場合, } \\
\text { それを実施する(人が所 } \\
\text { 属する) 組織はどこか. }\end{array}$ & 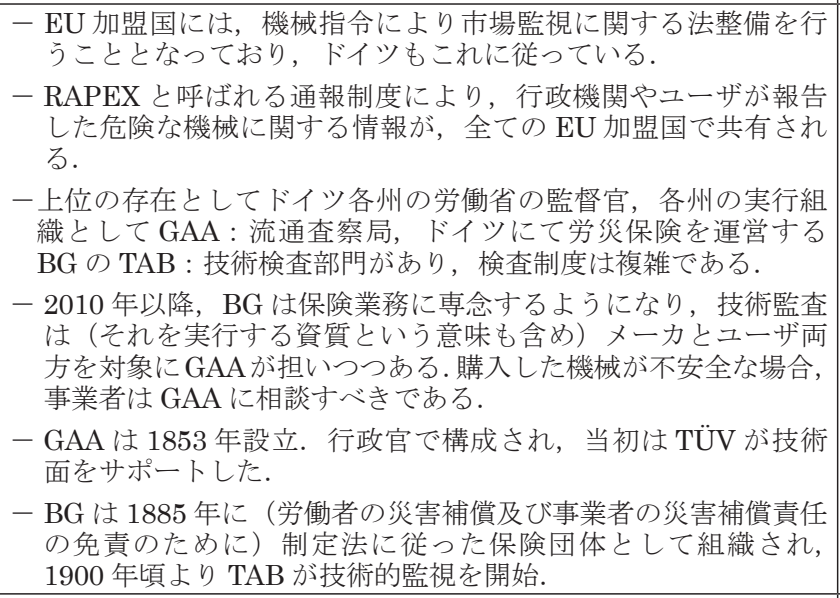 & 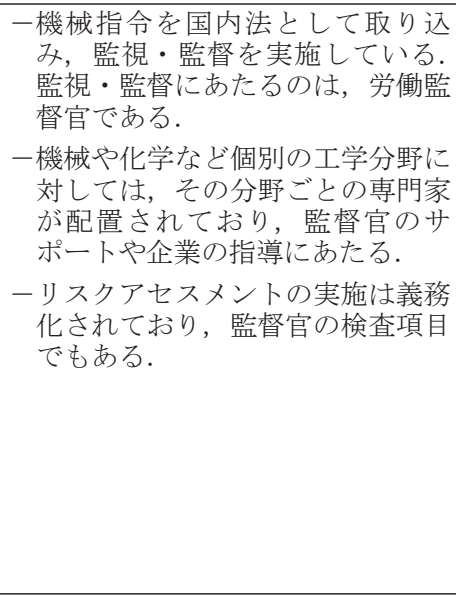 \\
\hline $\begin{array}{l}\text { (2)妥当性確認を受けないで } \\
\text { 機械を使用させた事業者 } \\
\text { には, どんなへナルルティ } \\
\text { が課せられるのか. }\end{array}$ & 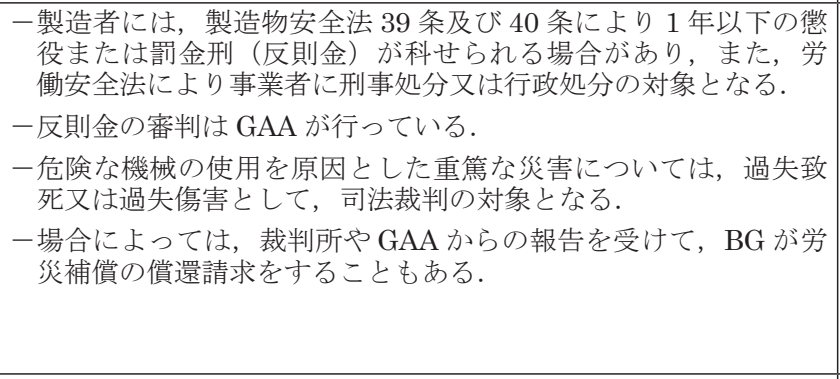 & 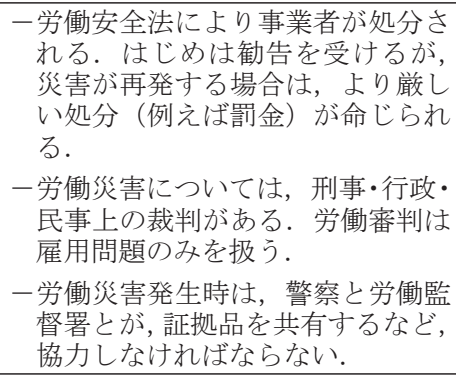 \\
\hline $\begin{array}{l}\text { (3)妥当性確認は新規購入時 } \\
\text { にのみ行うのか. その後 } \\
\text { も定期的に行うのか（行 } \\
\text { う場合は, その間隔) }\end{array}$ & 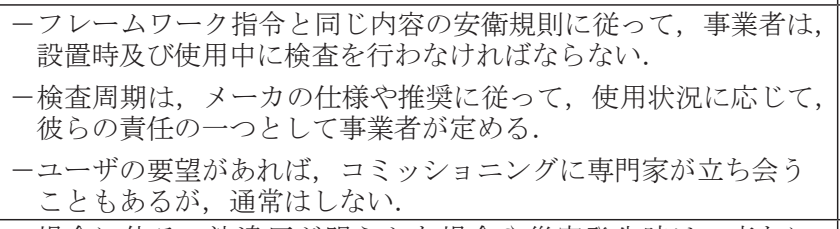 & $\begin{array}{l}\text {-従業員数 } 50 \text { 名以上の事業場は少 } \\
\text { なくも年に } 1 \text { 回, それ以下の行 } \\
\text { い企業では } 3 \text { 年に } 1 \text { 回は労働基準 } \\
\text { 監督官が検查に訪問する. }\end{array}$ \\
\hline $\begin{array}{l}\text { (4)妥当性確認の結果, 妥当 } \\
\text { でないと判断された場 } \\
\text { 合, 機械の使用が直ちに } \\
\text { 禁止される要な } \\
\text { 是正措置を指示し, 期限 } \\
\text { までの実施を再度確認す } \\
\text { るのか. }\end{array}$ & 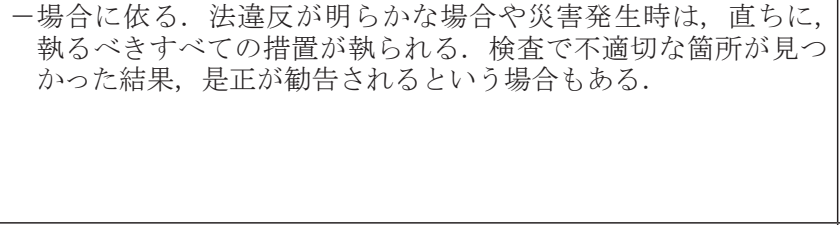 & $\begin{array}{l}\text { 一直ちに禁止される. } \\
\text { 一危険な機械を使用して災害が発生 } \\
\text { したと特定されれば, 労災保険料 } \\
\text { が著しく増加する. }\end{array}$ \\
\hline 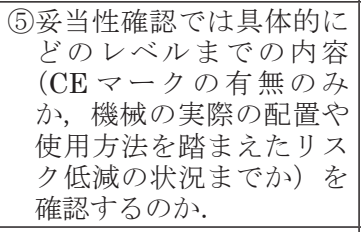 & $\begin{array}{l}\text { 一明確な欠陥を目視で検査するのが一般. 測定・試験までは通常 } \\
\text { 行われな. } \\
\text {-チェックリストを用意している組織もある. }\end{array}$ & $\begin{array}{l}\text { －はじめに目視で検查する. 必要に } \\
\text { 応じて, 安全距離などを計測する. }\end{array}$ \\
\hline $\begin{array}{l}\text { (6)複数の機械がコンベヤや } \\
\text { リフトなどによって接続 } \\
\text { された一連の生産システ } \\
\text { さ (EN ISO 11161) に } \\
\text { 対しては, 具体的にどの } \\
\text { レベルまでの内容 (CE } \\
\text { マークの有無のみか, 機 } \\
\text { 械の実際の配置や使用方 } \\
\text { 法を踏まえたリスク低減 } \\
\text { の状況までか)を妥当性 } \\
\text { 確認で確認するのか. }\end{array}$ & $\begin{array}{l}\text { - IMS を有する企業は一般に大企業であり，そのため，自社で社 } \\
\text { 内基準や検查手順等を完備している場合が多い. }\end{array}$ & $\begin{array}{l}\text { - IMS の立ち上げに, 監督官が立 } \\
\text { ち会うことはない. 認証団体が } \\
\text { 検証に立ち合う場合はある. } \\
\text {-現時点では, IMS 用のチェック } \\
\text { リストやガイドラインはないであ } \\
\text { 万う. }\end{array}$ \\
\hline $\begin{array}{l}\text { (7)妥当性確認のための手 } \\
\text { 順や書やチェックリストは } \\
\text { あるか. }\end{array}$ & $\begin{array}{l}\text { - 技術的要求事項は EN 規格に基づく. } \\
\text {-しばしば BGがガイドなどの情報を公開しているが，事業者が } \\
\text { 自らチェックリストを作るのが基本である. } \\
\end{array}$ & $\begin{array}{l}\text { 一公式なものは無い. } \\
\text { - INRS がチェックリストやガイド } \\
\text { を公表している. } \\
\end{array}$ \\
\hline $\begin{array}{l}\text { 8)定期的に改正される EN } \\
\text { 規格の情報を，検査実施 } \\
\text { 者にどのように知して } \\
\text { いるのか. }\end{array}$ & 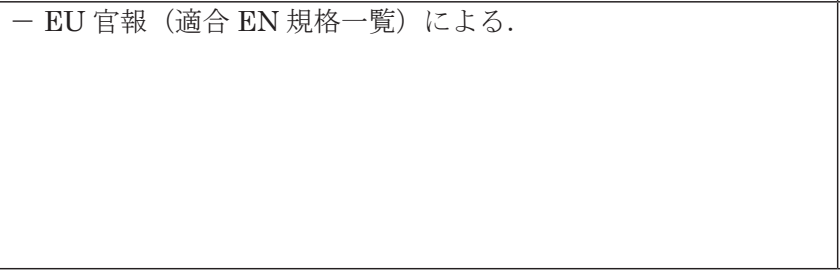 & $\begin{array}{l}\text { - 監督官は EU 官報をよく読む必要 } \\
\text { がある. } \\
\text {-フランス厚労省では, 社会的関係 } \\
\text { 者 (特に, 労働者代表) に対 } \\
\text { 規格作成作業への参加を支援して } \\
\text { いる (“Standardization and } \\
\text { French Public Authorities” 参 } \\
\text { 照). }\end{array}$ \\
\hline
\end{tabular}




\begin{tabular}{|c|c|c|}
\hline 質問事項 & ドイツ回答 & フランス回答 \\
\hline $\begin{array}{l}\text { (9)妥当性確認の対象になる企業 } \\
\text { の規模に応じて実施される妥 } \\
\text { 当性確認の内容や是正措置に } \\
\text { 違いはあるか. }\end{array}$ & $\begin{array}{l}\text { - 基本的に違いはない. } \\
\text { - 安全職場のモデルという意味で, 大企業に多くの活動が } \\
\text { 要請される場合はある. } \\
\text { - 平均値としての安全のレベルは日本とドイツでほぼ同じ } \\
\text { であるが,できの良い企業とそうでない企業との格差は, } \\
\text { 日本ほうがより大きいと感じている. }\end{array}$ & $\begin{array}{l}\text { 一違いはない. 是正措置は, 企業規模 } \\
\text { に応じて step-by-step で講じられて } \\
\text { いく. }\end{array}$ \\
\hline $\begin{array}{l}\text { (10中小企業が営働安全衛生のた } \\
\text { めの設備対策を行うの推進 } \\
\text { するための公的なサポート体 } \\
\text { 制はあるか. }\end{array}$ & 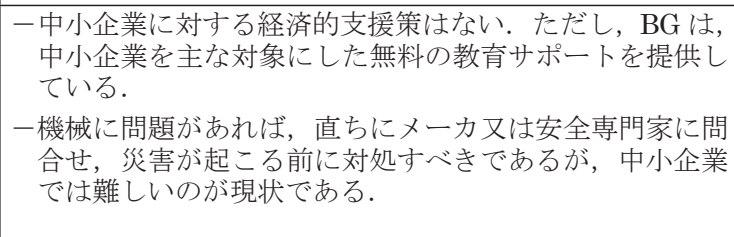 & $\begin{array}{l}\text { 一州にはない. 社会保険組織が, 安全 } \\
\text { 対策導入の祭の経済的支援をする場 } \\
\text { 合がある.身障者を雇用する際の設 } \\
\text { 備支援と同様のものである. } \\
\text {-災害発生のない企業とそうでない企 } \\
\text { 業とでは, 労災保佒料率が } 3-4 \text { 倍 } \\
\text { 異なる. }\end{array}$ \\
\hline $\begin{array}{l}\text { (11)現行の機械指令は } 2006 \text { 年に } \\
\text { 改正されたも无あるが, } \\
2006 \text { 年以前に設置された機 } \\
\text { 械も妥当性確認の対象になる } \\
\text { か. 妥当性確認の結果, 妥当 } \\
\text { でないと判断された場合, 機 } \\
\text { 械の使用は直ちに禁止される } \\
\text { のか. }\end{array}$ & $\begin{array}{l}\text { 一発行日以前に製造されたものについては適用しない. 機 } \\
\text { 械指令登行以前の機械については, 労働安全規則又は } \\
\text { BGの災害防止規定が適用される. } \\
\text {-ただし, 法的要求事項及び安全衛生規則の付属書 } 1 \text { の最 } \\
\text { 低要求事項 (フレー同等) } \\
\text { は満足する必要がある. }\end{array}$ & $\begin{array}{l}\text { 一発行日以前に製造されたものについ } \\
\text { ては適用しない. } \\
\text { 一中古機械も同様である. ただし, 購 } \\
\text { 入の際, 改造等が行われて基準への } \\
\text { 適合が損なわれていないか, 確認す } \\
\text { る必要がある. }\end{array}$ \\
\hline $\begin{array}{l}\text { (12)機械指令は EU 圈内での円滑 } \\
\text { な製品流通を目的に制定され } \\
\text { たものであるが, 労働災害防 } \\
\text { 止の観点から見て, その内容 } \\
\text { に不足している点・改善すべ } \\
\text { き点があるか. }\end{array}$ & $\begin{array}{l}\text { 一機械個別の安全規格は, 適用範囲の標淮的な機械の重要 } \\
\text { な危険源について扱っているが, そで規さ定されていな } \\
\text { い機械指令が指摘する他の危険源を見落としているメー } \\
\text { カが多い. }\end{array}$ & $\begin{array}{l}\text { 一機械指令は state of the art に基づい } \\
\text { ていると思っている. } \\
\text { 一ユーザの意見は, 認証団体での会合 } \\
\text { などを通じて把握される. }\end{array}$ \\
\hline (13)その他 & 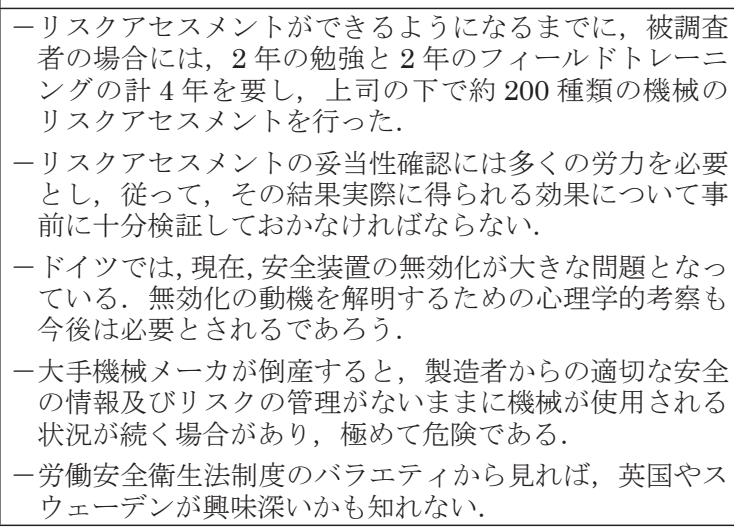 & 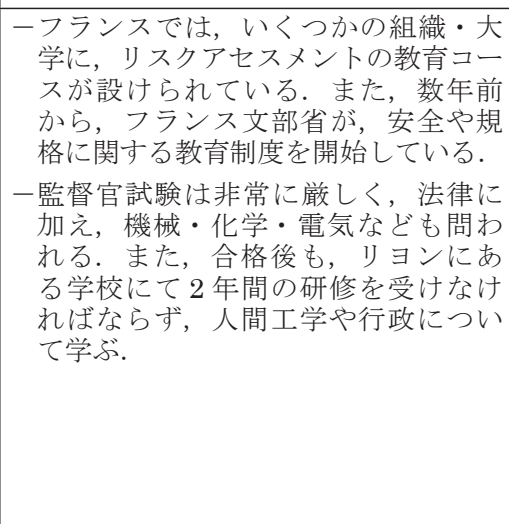 \\
\hline
\end{tabular}

者や国際競争の場で活躍している企業の担当者などから は“機械安全に関する規制を日本と欧州で完全に整合化 すべき”，“日本でも ISO/IEC 規格をそのまま強制法規 として採用すべき”との意見がある.

一方で，特に日本国内の中小零細企業からは “過度の 国際整合化はコストアップに繋がるだけで，技術力の点 からも対応に不安がある”との意見も根強い. したがっ て，本案の検討にあたっては，働く人の安全を確実に確 保した上で，上記の意見を踏まえた対応が必要になると 考えられる.

\section{2）実質同一案}

この案は，欧州の法規制や社会制度の中から特に労働 災害防止効果が高いと考えられるエッセンスを抽出し， 労働安全衛生法などに強制法規として反映させる案であ る. 具体的には，機械の設計・製造者が行う方策として， ISO 12100 のステップ 1 及び 2 に定める本質的安全設計 方策や安全防護（ガードや保護装置）及び制御システム の安全関連部に対する方策（インタロック,フェールセー フ，タンパープルーフなど）を労働安全衛生規則の一般 基準などに規定し，かつ適合性評価，第三者認証及びマー
キングなどの制度の内容を労働安全関係法令に規定する 案である。

図 8 に，実質同一案における機械のリスク低減戦略の 例を示す。この案では, (1) ISO12100に定めるリスク低 減戦略 (図 2 参照), (2)モジュール方式による適合性評価 （図 4 参照）と適合宣言に関する情報伝達を目的とした マーキング，(3)機械の使用者による妥当性確認，(4)機械 の設計・製造段階での災害情報の活用を基本要素とした。

このうち，(1)と(2)は製品の自由な流通を目的とする欧 州の機械安全制度の中心となる機能である。これに対し， 図 8 では，日本で望まれる機械安全に関する法規制及び 社会制度として，労働者の安全を確保するために(3)と (4) の機能も併せて重視している.

以上の案では, ISO 12100 のステップ 1 及び 2 に定め る本質的安全設計方策や安全防護及び制御システムの安 全関連部に対する方策だけで十分な労働災害防止効果が 得られるかという懸念がある。そこで，筆者らが約 10 年 前に実施した機械に起因する労働㷋害の分析結果 ${ }^{19)}$ を利 用して，このときの労働災害防止効果を推察した。

表 7 に，この分析結果をまとめた結果を示す。この分 


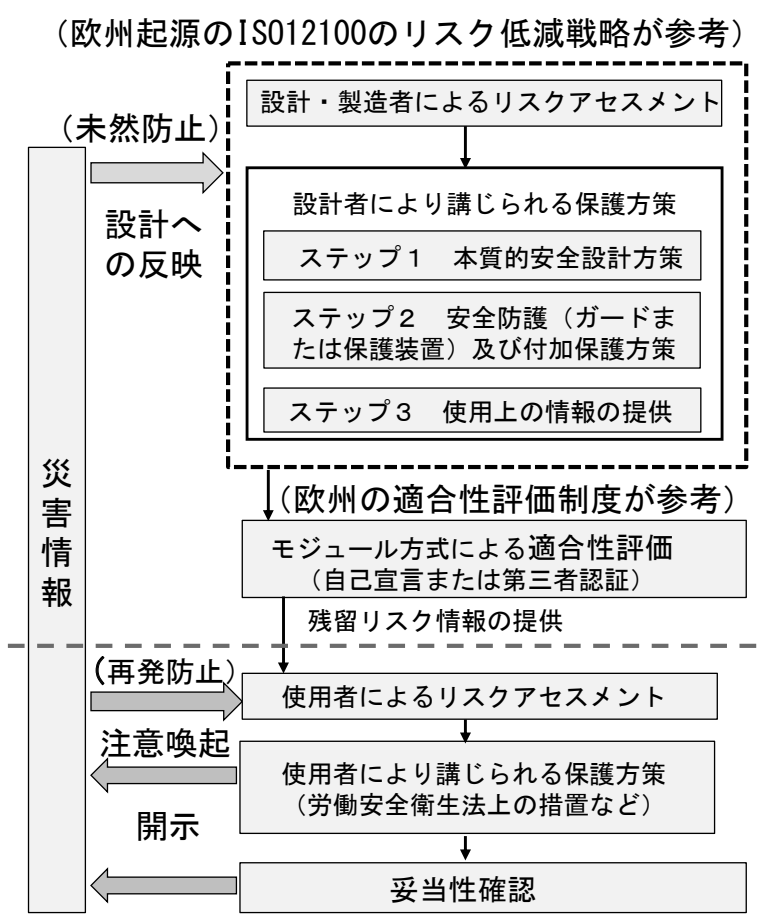

図 8 欧州方式の機械安全制度に基づく災害防止戦略 ${ }^{14)}$

表7 保護方策の不具合に関連した災害 ${ }^{19)}$

\begin{tabular}{c|l|l}
\hline & \multicolumn{1}{|c|}{ 設備の種類 } & \multicolumn{1}{|c}{ 件数 } \\
\hline (1) & 固定式ガード & $45(34.9 \%)$ \\
(2) & インタロック式ガード & $67(51.9 \%)$ \\
(3) & (1)+(2) (ガード) & $87(67.4 \%)$ \\
(4) & 保護装置 & $31(24.0 \%)$ \\
(5) & 制御システムの安全関連部 & $30(23.3 \%)$ \\
\hline & 総計 & $102(79 \%)$ \\
\hline
\end{tabular}

首都圈で発生した産業機械による死亡労働災害 129 件を分 析したところ, 設備対策の不具合に起因した災害が $79.1 \%$ を占めていた。

・ (1)〜(5には重複あり。挟まれ・巻き込まれ災害 125 件, 激 突され災害 4 件. ただし, 車両系荷役運搬機械と建設機械 は分析の対象から除外。

析では, 首都圈で発生した機械に起因する “挟まれ・巻 き込まれ”災害と “激突され” 災害を事故の型とする死 亡労働災害 129 件を対象とした ${ }^{19)}$.

分析の結果，少なくともステップ 2 の安全防護（ガー ドまたは保護装置）及び制御システムの安全関連部に対 する対策（インタロック，フェールセーフなど）を実施 すれば，機械による労働災害の 8 割近く（79\%）を防止 できることが推察された。 また，ガード（固定式及びイ ンタロック式）を利用した対策だけでも，機械による労 働災害の 3 分の 2 近く（67\%）を防止できることが推察 された.ただし，この結果は死亡労働災害を対象とした もので，障害を伴う災害や休業災害に対してまで有効か は別途検証する必要がある。また，この分析を実施して から約 10 年近くが経過しているので, 現在も上記の推察 が有効かも別途検証する必要がある.

\section{3）現在の規制を強化する案}

この案は, 努力義務である労働安全衛生法第 28 条の 2 (危険性又は有害性に関する調査等）や，ISO12100 と 実質同一である「機械の包括的な安全基準に関する指針」 を適切に運用することによって，機械による労働災害を
防止しようとするものである.

この案の問題点は, 前述した法令や通達に強制力がな い点にある.このため, 安全活動に熱心な事業者が機械 安全に熱心に取り組む一方で, 災害発生率の高い事業者 が強制でないという理由から熱心に取り組みを行わない という傾向が懸念される.

また，これらの規制では，事業者が自主的にリスクア セスメントに取り組むことが重要と考えられている。し かし，第 2 章の 2) で述べたように，イギリスなどではリ スクアセスメントは主に中小零細企業がリスクの概念を 習得する際の教材に過ぎない。むしろ, 中小零細企業で は本質的安全設計方策や安全防護（ガードまたは安全装 置) などの設備対策を重点に置いた方策の展開が重要で あり, この点を考慮した方策の検討が必要と考えられる.

\section{4）完全整合化案と実質同一案の融合}

有識者からの意見では, 働く人の安全（労働者保護） と企業の国際競争力の強化を両立させる方策も要請され ている，このために考えられるのが，完全整合化案と実 質同一案の融合である.

具体的には，労働安全衛生規則の一般基準に，(1)本質 的安全設計方策や安全防護及び制御システムの安全関連 部に対する方策を規定するとともに, (2) ISO/IEC などの 機械安全国際規格の要求事項を満足できる機械は(1)の要 求事項を満足していると「みな寸」または「推定する」 規定を設けるなどの方法が考えられる，ただし，この案 では労働安全衛生規則と ISO/IEC などに規定された安全 性に関する内容の水準が実質的に同等でないと不公平を 生じるおそれがある。このため, 前述した欧州と日本の 安全に関する基本理念の融合を図るなどの方策が必要と なる.

この点で参考になるのが食品加工用機械の労働災害防 止対策である。この機械では, 平成 25 年に労働安全衛生 規則第 130 条の $2 \sim 9$ が強制法規として定められた.一方, 食品加工用機械の業界では, 望ましい技術的な要求事項 を順次 JIS として制定して行くという施策を展開してい る.これによって, 働く人の安全と企業の競争力強化の 両立を目指している.

\section{5 おわりに}

本稿は，今後の日本で望まれる機械安全に関する法規 制及び社会制度のあり方について検討した結果をまとめ たものである.

具体的には, 日本の現場力及び欧州の機械安全に関す る法規制と社会制度の内容と実態を調査・分析するとと もに，現段階で想定できる日本での法規制案及び社会制 度案を複数設定し, 各提案の労働災害防止効果や実現可 能性及び問題点などの検証を行っている. このうち, 現 段階までに得られた主な結果は次のとおりである。

1）日本の強夕は，現場の優秀な作業者や管理・監督者 及び生産技術者が質の高い安全管理と生産技術に基づ く改善を実施していることにある。したがって，この “現場力”を基盤に置いた上で，欧州の機械安全技術や

Vol. 8, No.1, pp.13-27, (2015) 
社会制度を適切に活用すれば，日本の現場力と欧州の 機械安全技術を高次の次元で融合させた新しい枠組み の安全技術と社会制度を構築できる可能性がある。こ れは，働く人の安全（労働者保護）だけでなく日本の 国際競争力の強化という観点からも意義がある.

2）今後の日本の社会制度では，安全をコストでなく新 たな価值創造のための投資として位置づけること，高 い当事者意識と安全な職場を構築しようとする共通の 価值観を関係者間で共有すること，及び再発防止から 未然防止，件数重視から重篤度重視への戦略転換と想 定外の考慮が重要と推察された。

3）実際の労働災害防止対策では，経営者及び設計者に 対して欧州機械安全の基本理念と災害防止原則を普及 促進するとともに，(1) ISO12100に定めるリスク低減 戦略，(2)モジュール方式による適合性評価と適合宣言 に関する情報伝達を目的としたマーキング，(3)マーキ ングの情報に基づく機械の使用段階での妥当性確認, (4)機械の設計・製造段階への災害情報のフィードバッ クが特に重要と考えられた。

今後は，働く人の安全の確保は当然として，企業の国 際競争力の強化，安全に関連する新産業の創出，海外と の相互承認に基づく適合性評価に要するコストの削減, 設備の生産性，作業性，保全性，費用対効果の改善とい う観点からも研究を進める予定でいる。

\section{謝辞}

本稿は，厚生労働科学研究費 “機械安全規制における 世界戦略へ対応するための法規制等基盤整備に関する調 查研究”（H25 - 労働- 一般－001）の補助金による成 果を踏まえて作成したものである。本補助金の提供に御 尽力頂いた関係各位に深い謝意を表する.

\section{文献}

1）機械の CE マーキング。日経メカニカル別冊. 日経 BP 社 (1994).

2）梅崎重夫，条川壮一，機械安全に関する欧州規格の現状と 国内法規との対応に関する調査. 産業安全研究所安全資料. 1996; NIIS-SD-No.14. 1-14.

3）梅崎重夫，清水尚憲，濱島京子，平沼栄浩，高木元也，島 田行泰，三平律雄。よくわかる! 管理・監督者のための安全 管理技術一管理と技術のココがポイントー(基礎編)。日科技 連出版社；2011。

4）機械安全規制における世界戦略へ対応寸るための法規制等
基盤整備に関する調查研究. 厚生労働科学研究費平成 25 年 度総括研究年度終了報告書 $; 2014$.

5）遠藤功. 現場力の教科書. 光文社新書 ; 2012 .

6）若松義人．最強の現場を作り上げる！トヨタ式「改善」の 進め方. PHP ビジネス新書 ; 2007: 122-126.

7）労働省安全課監修。これからの安全技術一工作機械等の制 御機構のフェールセーフ化に関するガイドラインの解説一. 安全確認システムと生産性（杉本旭と梅崎重夫で執筆）； 2000: 190-193.

8）古澤登. 元気な職場を作る実践的安全活動一安全スタッフ 管理監督者が組織を変える一。中災防新書; 2012 .

9）梅崎重夫，清水尚憲，濱島京子，木下博文，平沼栄浩，宮 崎浩一，石坂清．統合生産システム (IMS) におけるリスク 低減プロセスの基礎的考察，労働安全衛生研究．2008; 1(3): $212-219$.

10）栗原史郎監修, 向殿政男ほか. 現場発ものづくり革新一安 全は競争力。日刊工業新聞社；2009.

11）遠藤功. 現場力復権. 東洋経済新聞社 ; 2009 .

12）中村昌充. 製造現場の事故を防ぐ安全工学の考え方と実践。 オーム社; 2013.

13）朱宮徹. 現場力の高い職場づくり。労働の科学. 2013; 68(12): 10-14.

14）梅崎重夫, 板垣晴彦, 齋藤剛, 伊藤和也, 山際謙太, 崔光石, 高橋弘樹，濱島京子，清水尚憲，大幢勝利。よくわかる! 管 理・監督者のための職場における安全工学. 日科技連出版社 2013: $1-16$

15）梅崎重夫，濱島京子，清水尚憲. 機械安全と安全管理にお ける基本理念と災害防止原則の比較ーベスト・プラクティス の観点から. 労働科学. 2010; 86(4): 217-225.

16）中山和久. 国際労働法.三省堂；1998: 46-54.

17) ISO/OHS 研究会編. ISO 安全・品質・環境早わかり．日本 規格協会；1997: 71-83.

18）杉本旭，蓬原弘一．安全の原理．日本機械学会論文集 $\mathrm{C}$ 編 1990; 55(530): 2601-2609.

19）梅崎重夫，清水尚憲．産業機械の労働災害分析．産業安全 研究所特別研究報告. NIIS-SRR. 2005; 33: .53-67.

「補足 1」図 3 に示した本質的安全設計方策のうち 7) 及 び 8) はISO12100に明記されていない。しかし，“危険 源の除去” は本質的安全設計方策でも優先して採用す心゙ き方策であり，上記 7）及び 8）が危険源の除去に該当す るという理解は欧州でも一般的である。このため，本稿 では上記 7）及び 8）も含めた上で本質的安全設計方策の 例を示した。 


\section{Discussion of the social system and regulations related to safety of machinery in Japan \\ by \\ Shigeo UMEZAKI ${ }^{* 1}$, Takabumi FUKUDA ${ }^{* 2}$, Tsuyoshi SAITO ${ }^{* 1}$, Shoken SHIMIZU*1, Tetsuya KIMURA $^{* 2}$, Kyoko HAMAJIMA ${ }^{* 3}$, Toshiro HoshI ${ }^{* 4}$, Hiroyasu IKEDA ${ }^{* 1}$, Kohei OKABE $^{* 1}$, Kenta YAMAGIwA ${ }^{* 1}$, Hajime TOMiTA ${ }^{* 3}$, Yoshiki MiKAMI ${ }^{* 2}$, Yuji HIRAO $^{* 2}$, Makiko OKAMOTO ${ }^{* 2}$, Satoshi KADOWAKI ${ }^{* 2}$, Masajiro ABE ${ }^{* 2}$ and Yuichi OTSUKA ${ }^{* 2}$}

An advantage of Japan is that high-quality safety management and production technologies have been implemented at worksites by workers, managers and production engineers. If European technologies and social systems for safety of machinery are appropriately implemented on the basis of these "onsite capabilities," a new technology and social system framework based on Japan's own onsite capabilities may be created. This study examined the laws, regulations, and social systems that are favorable for safety of machinery in Japan. In maximizing onsite capabilities for safety management, the following four activities were presumed important: (1) the positioning of safety as an investment for new value creation, not a cost; (2) the sharing of a strong sense of ownership and common values for building a safe workplace among involved individuals; (3) the changes in strategies from prevention of recurrence to proactive prevention and from considering the number of accidents to considering the severity of accident; and (4) the consideration of unexpected problems.

In addition to the aforementioned activities, the basic principles of machine safety and accident prevention in Europe were considered particularly important for spreading and promotion among corporate executives and machine designers. These principles are the (1) risk reduction strategies provided by the International Organization for Standardization (ISO 12100); (2) conformity assessments that use a modular approach and marking aimed at conveying information about declarations of conformity; (3) validity confirmation when using a machine based on marking information; and (4) feedback regarding disaster information for the design and manufacturing stages of a machine.

Key Words: safety of machinery, regulations, social system, ISO12100, validation

\footnotetext{
*1 Mechanical and System Safety Research Group, National Institute of Occupational Safety and Health, Japan

*2 Nagaoka University of Technology

*3 Electrical Safety Research Group, National Institute of Occupational Safety and Health, Japan

*4 Ministry of Health, Labour and Welfare
} 
